\title{
Sequential emergence and clinical implications of viral mutants with K70E and K65R mutation in reverse transcriptase during prolonged tenofovir monotherapy in rhesus macaques with chronic RT-SHIV infection
}

\author{
Koen KA Van Rompay*1, Jeffrey A Johnson ${ }^{2}$, Emily J Blackwood ${ }^{1}$, \\ Raman P Singh1, Jonathan Lipscomb², Timothy B Matthews ${ }^{3}$, \\ Marta L Marthas ${ }^{1}$, Niels C Pedersen ${ }^{4}$, Norbert Bischofberger ${ }^{5}$, \\ Walid Heneine ${ }^{2}$ and Thomas W North ${ }^{3,6}$
}

Address: ${ }^{1}$ California National Primate Research Center, University of California, Davis, USA, ${ }^{2}$ Division of HIV/AIDS Prevention, National Center for HIV, STD and Tuberculosis Prevention, Centers for Disease Control and Prevention, Atlanta, USA, ${ }^{3}$ Center for Comparative Medicine, University of California, Davis, USA, ${ }^{4}$ Department of Medicine and Epidemiology, School of Veterinary Medicine; University of California, Davis, USA, ${ }^{5}$ Gilead Sciences, Foster City, USA and ${ }^{6}$ Department of Molecular Biosciences, School of Veterinary Medicine, University of California, Davis, USA

Email: Koen KA Van Rompay* - kkvanrompay@ucdavis.edu; Jeffrey A Johnson - jlj6@cdc.gov; Emily J Blackwood - emib44@yahoo.com; Raman P Singh - Raman.Singh@mwumail.midwestern.edu; Jonathan Lipscomb - eyk1@cdc.gov;

Timothy B Matthews - tbmatthews@ucdavis.edu; Marta L Marthas - mlmarthas@ucdavis.edu; Niels C Pedersen - ncpedersen@ucdavis.edu; Norbert Bischofberger - norbert.bischofberger@gilead.com; Walid Heneine - wmh2@cdc.gov; Thomas W North - twnorth@ucdavis.edu

* Corresponding author

Published: 6 April 2007

Retrovirology 2007, 4:25

doi:10.1 186/1742-4690-4-25
Received: 16 January 2007

Accepted: 6 April 2007

(C) 2007 Van Rompay et al; licensee BioMed Central Ltd.

This is an Open Access article distributed under the terms of the Creative Commons Attribution License (http://creativecommons.org/licenses/by/2.0), which permits unrestricted use, distribution, and reproduction in any medium, provided the original work is properly cited.

\begin{abstract}
Background: We reported previously on the emergence and clinical implications of simian immunodeficiency virus (SIVmac25I) mutants with a K65R mutation in reverse transcriptase (RT), and the role of CD8+ cell-mediated immune responses in suppressing viremia during tenofovir therapy. Because of significant sequence differences between SIV and HIV-I RT that affect drug susceptibilities and mutational patterns, it is unclear to what extent findings with SIV can be extrapolated to HIV-I RT. Accordingly, to model HIV-I RT responses, 12 macaques were inoculated with RT-SHIV, a chimeric SIV containing HIV-I RT, and started on prolonged tenofovir therapy 5 months later.

Results: The early virologic response to tenofovir correlated with baseline viral RNA levels and expression of the MHC class I allele Mamu-A*0I. For all animals, sensitive real-time PCR assays detected the transient emergence of K70E RT mutants within 4 weeks of therapy, which were then replaced by K65R mutants within 12 weeks of therapy. For most animals, the occurrence of these mutations preceded a partial rebound of plasma viremia to levels that remained on average 10 -fold below baseline values. One animal eventually suppressed $K 65 \mathrm{R}$ viremia to undetectable levels for more than 4 years; sequential experiments using CD8+ cell depletion and tenofovir interruption demonstrated that both CD8+ cells and continued tenofovir therapy were required for sustained suppression of viremia.

Conclusion: This is the first evidence that tenofovir therapy can select directly for K70E viral mutants in vivo. The observations on the clinical implications of the K65R RT-SHIV mutants were consistent with those of SIVmac25I, and suggest that for persons infected with K65R HIV-I both immune-mediated and drug-dependent antiviral activities play a
\end{abstract}


role in controlling viremia. These findings suggest also that even in the presence of $\mathrm{K} 65 \mathrm{R}$ virus, continuation of tenofovir treatment as part of HAART may be beneficial, particularly when assisted by antiviral immune responses.

\section{Background}

Tenofovir (9-[2-(phosphonomethoxy)propyl]adenine; PMPA) is a commonly used antiretroviral compound which selects for the K65R mutation in reverse transcriptase (RT); this mutation is associated with a 2- to 5fold reduced in vitro susceptibility to tenofovir [1,2]. Many tenofovir-containing regimens induce strong and longlasting suppression of viremia in the majority of persons, with a low occurrence of the K65R mutation [1,3-5]; the emergence of K65R mutants in such patients was not always associated with a viral rebound $[1,5,6]$. However, a lower virologic success rate has been observed when tenofovir was used in specific combinations with other drugs with overlapping resistance profile (e.g., lamivudine, didanosine and abacavir), and the K65R mutation was found in approximately $50 \%$ of patients with a less-thandesired virologic response on such regimens [6-11].

Although much progress has been made [12], many unresolved questions remain regarding the exact virulence and clinical implications of drug-resistant viral mutants, and how to use this information to make treatment decisions. This is also true for K65R viral mutants. While the K65R mutation reduces replication fitness of HIV-1 in vitro relative to wild-type virus [13], it is unclear to which extent this can be extrapolated to virus replication fitness in vivo, especially when K65R is accompanied by other mutations in RT; some mutations may be compensatory (to improve replicative capacity), while the combination of $K 65 \mathrm{R}$ with certain other drug-selected mutations may be deleterious for viral replicative capacity (e.g., L74V, certain thymidine-analogue mutations), or may restore viral susceptibility to other compounds of the drug regimen [14-17]. It is also unclear whether the detection of K65R HIV-1 mutants is a valid criterion for withdrawing tenofovir from the patient's regimen, as it is possible that tenofovir still exerts some residual antiviral activity in vivo against replication of K65R HIV-1.

Simian immunodeficiency virus (SIV) infection of macaques has been a useful animal model to study the emergence, virulence and clinical implications of viral mutants during drug treatment [18]. Prolonged tenofovir monotherapy of macaques infected with virulent SIVmac251 resulted in the emergence of mutants with the K65R mutation in RT $[19,20]$. In the absence of tenofovir treatment, these K65R SIV isolates replicated in vivo to high levels and induced a disease course indistinguishable from that of wild-type virus [21]. In the presence of tenofovir treatment, however, disease-free survival was improved significantly, and some animals were able to suppress viremia of $\mathrm{K} 65 \mathrm{R}$ virus to low or undetectable levels for 4 to more than 10 years [20-22]. Further experiments, using in vivo CD8+ cell depletions and treatment interruption, revealed that this suppression of $\mathrm{K} 65 \mathrm{R}$ viremia depended on strong CD8+ cell-mediated immune responses, but that continued tenofovir therapy was also still necessary [20]. However, even when K65R viremia was not suppressed, continued tenofovir treatment was, surprisingly, associated with clinical benefits (i.e., diseasefree survival) that were larger than predicted based on viral RNA levels and standard immune markers [22].

Because there are some important differences in the amino acid sequence of HIV-1 and SIV RT which affect susceptibilities and the mutational patterns to antiviral drugs [23], it is unclear to what extent these findings from the SIV model regarding the in vivo emergence, virulence and clinical implications of K65R viral mutants during tenofovir treatment can be extrapolated to HIV-1 RT. Some experimental procedures (such as CD8+ cell depletions, or prolonged tenofovir monotherapy), however, are not ethically or logistically feasible to study in HIV-1 infected humans. Because there is so far no optimal animal model that uses HIV-1, the currently best approach to unravel such questions about HIV-1 RT is the use of macaques infected with RT-SHIV, a chimeric virus consisting of SIVmac239 in which the RT gene is replaced by the counterpart of HIV-1 [24,25]. While RT-SHIV is virulent in macaques, the early studies (which used small animal numbers) found that viremia and the rate of disease progression were variable and on average lower than that observed with SIVmac239 or with other virulent SIV isolates, such as SIVmac251 [20,25-28]; this is likely because the insertion of a foreign RT into SIV affected its replicative ability [24]. Thus, a long-term study was performed to address the following questions through sequential experiments: (i) does in vivo passage of RT-SHIV lead to higher or more consistent virulence, (ii) does prolonged tenofovir treatment initiated during chronic RT-SHIV infection lead to the emergence of K65R viral mutants, (iii) what are the clinical implications of K65R mutants, and (iv) what is the role of CD8+ cells and continued tenofovir treatment in controlling viremia of K65R RT-SHIV?

The current report is the first one to demonstrate that during prolonged tenofovir therapy, RT-SHIV infected animals developed first K70E mutants, which were then replaced by K65R mutants. Further experiments in one animal that suppressed $\mathrm{K} 65 \mathrm{R}$ viremia to undetectable lev- 
els demonstrated that, similarly to the findings in the SIVmac251 model, both CD8+ cell-mediated antiviral immune responses and continued tenofovir therapy were important to obtain maximal suppression of RT-SHIV viremia. This suggests that maintaining tenofovir as part of HAART, particularly when CD8+ cell-mediated immune responses are good and no better therapies are available, may still offer clinical benefits to persons infected with K65R mutants.

\section{Results}

In vivo passage of RT-SHIV and establishment of persistent infection

Although the molecular clone of RT-SHIV is virulent in macaques, earlier studies found that infection resulted in a variable peak and set-point of viral RNA levels in plasma [24,26-28]. In an attempt to further increase its virulence, the cloned virus was subjected to 2 sequential in vivo passages (Fig. 1). A first group of 3 animals (group A) was inoculated intravenously with $10^{5} \mathrm{TCID}_{50}$ of in vitro propagated RT-SHIV. Plasma collected two weeks after infection was pooled and $0.6 \mathrm{ml}$ of this pool (containing 19 $\times 10^{6}$ viral RNA copies; 1,400 TCID $_{50}$ ) was administered intravenously to a second group of 4 animals (Fig. 1, group B). The same procedure was repeated, and $0.6 \mathrm{ml}$ pooled plasma collected from group B animals at 2 weeks of infection $\left(\sim 10 \times 10^{6}\right.$ viral RNA copies; $~ 1,000$ TCID $\left._{50}\right)$ was injected intravenously into 5 animals (Fig. 1, group C). Peak virus levels for animals of all 3 groups were observed at 1 to 2 weeks after infection and ranged from 9 to 43 million copies RNA per ml plasma (Fig. 1A), and 2,200 to $32,000 \mathrm{TCID}_{50}$ per million PBMC (data not shown). The rapid serial passage in macaques did not have any detectable effect. The 3 animal groups had similar viral RNA levels in plasma and infectious titers in PBMC, and a similar decline in absolute counts and percentages of CD4+ T lymphocytes and CD4+/CD8+ T cell ratios during the first 20 weeks of infection (two-way ANOVA: p values of passage effect $>0.05$; Fig. 1). During the first 20 weeks of infection, all 12 animals had a decrease in absolute CD4+ T cell counts (mean loss of 927 (range 480-1590) cells per $\mu \mathrm{l}$; Fig. 2B); this meant a median decrease of 55\% (range 28-83\%) of their absolute CD4+ T cell counts. All 12 animals mounted strong humoral immune responses to SIV, as the SIV-specific IgG titers in plasma (measured by ELISA) were $>102,400$ by eight weeks of infection (data not shown). There was no detectable difference among the three groups in response to subsequent tenofovir treatment and disease-free survival, and accordingly the groups are combined for the presentation of the remainder of the study.

\section{Tenofovir monotherapy of RT-SHIV infected macaques: early virologic and immunologic responses}

Untreated RT-SHIV infected macaques have generally little change in viremia once a viral set-point is established after $\sim 8$ to 12 weeks of infection $[25,26,29]$. In the current study, the 12 RT-SHIV animals were started on tenofovir monotherapy $(10 \mathrm{mg} / \mathrm{kg}$, subcutaneously once daily) at approximately 20 weeks of infection. This starting dose was selected because it is pharmacokinetically similar (based on plasma AUC levels of $\sim 20 \mu \mathrm{g} . \mathrm{h} / \mathrm{ml}$ ) to the intravenous tenofovir regimen of the initial human clinical trials [30]. Tenofovir treatment was associated with an average 10-fold decrease in viral RNA levels after 1 week of treatment (Fig. 2A). However, there was much individual variability; 10 animals had a decrease in plasma viral RNA levels (mean decrease: 21-fold; range: 2 to 53-fold), while the remaining 2 animals (numbers 30842 and 30478; Fig. 3) had no decrease after 1 week of treatment. Infectious virus titers in PBMC showed similar patterns as the plasma viral RNA levels (data not shown). The early effect of tenofovir therapy on the percentage of CD4+ T lymphocytes in peripheral blood was variable, as only half of the animals showed a relative increase of $\geq 3 \%$ within 2 weeks of therapy (Fig. 3). However, relative to the baseline value at the onset of tenofovir therapy, after 2 weeks of treatment all 12 animals had an increase in total lymphocyte counts (median increase of 51\% (range 22-272\%; $\mathrm{p}=0.001$, two-tailed paired t test), and 11 animals had an increase in absolute CD4+ T cell counts (mean change of +469 (range from -149 to +1291 ) cells per $\mu \mathrm{l}$; $\mathrm{p}=0.002$, two-tailed paired t test; Fig. $2 \mathrm{~B}$ ), which meant a median increase in absolute CD $4+\mathrm{T}$ cell counts of $71 \%$ (range of relative change: -21 to $+183 \%$ ). This significant increase in absolute CD4+ T cell counts was transient, as values returned to pre-therapy baseline values after 12 weeks of tenofovir therapy (32 weeks of infection; Fig. $2 \mathrm{~B}$; two-tailed paired t test $\mathrm{p}$ values $\geq 0.05$ ). Absolute CD4+ T cell counts then stabilized for most animals until they declined concomitantly with the development of clinical disease symptoms.

Three of the 12 animals expressed the major histocompatibility complex (MHC) class I allele Mamu-A*01; 4 other animals expressed the MHC class I Mamu-B*01 allele. Although there was no significant effect of the presence of either one of these alleles and viremia during the first 20 weeks of infection (prior to tenofovir therapy), Mamu$A^{*} 01$-positive animals responded initially to tenofovir therapy with lower viral RNA levels than Mamu-A*01negative animals (first 4 weeks of treatment, two-way ANOVA, effect of Mamu-A*01 $\mathrm{p}=0.02$; Fig. 4A). But between 8 to 20 weeks of tenofovir treatment (i.e., 28 to 40 weeks of infection), concomitant with the detection of viral mutants (see below), there was no significant differ- 


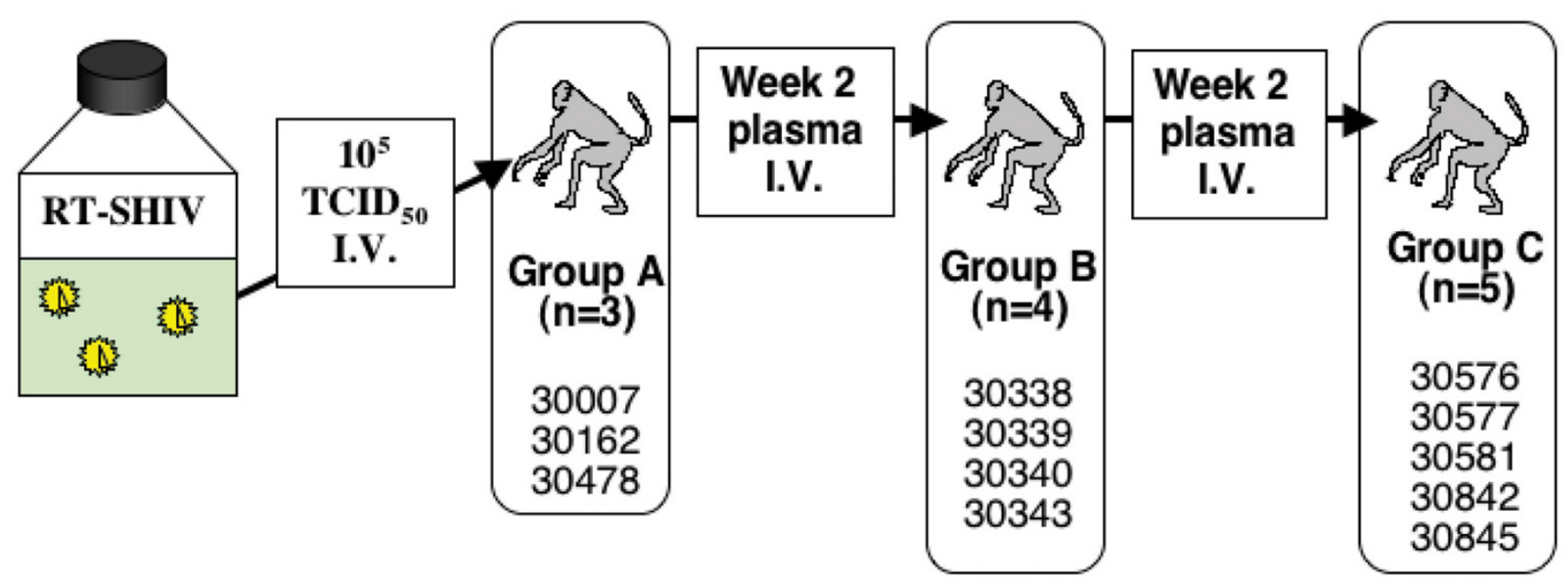

A. Plasma RNA

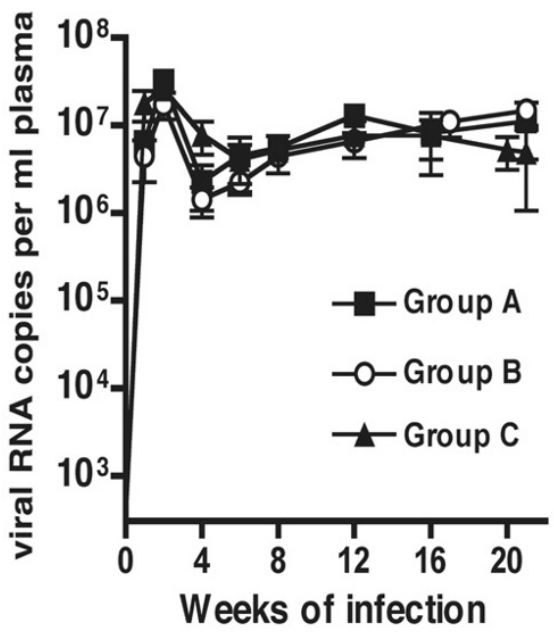

B. Absolute CD4+ T cells

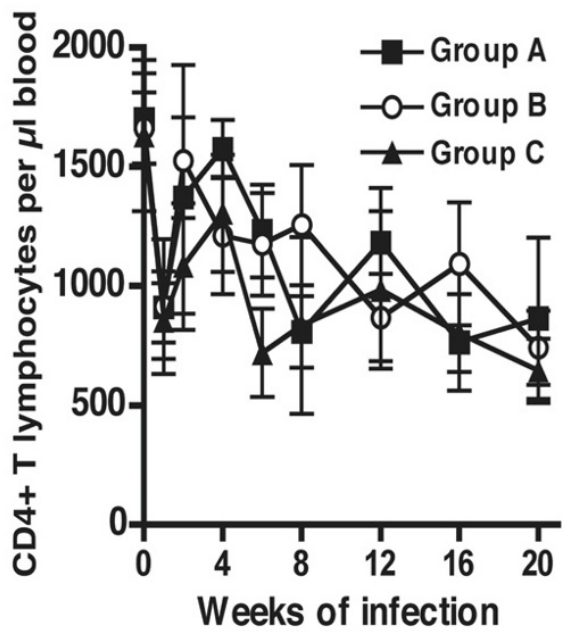

C. $\%$ CD4 T cells

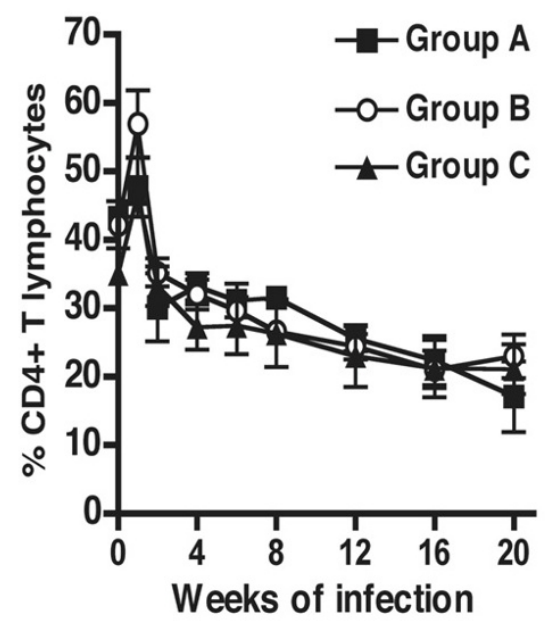

Figure I

Serial in vivo passage of RT-SHIV: effect on virulence. A high dose of RT-SHIV (I05 TCID 50$)$, propagated in vitro in CEMxI 74 cells, was inoculated intravenously in 3 animals (group A). Plasma collected 2 weeks later was pooled and administered intravenously to 4 animals (group B). The same procedure was repeated for the final passage into 5 animals (group C). There were no significant differences between the 3 groups with regard to viral RNA levels (calculated after log-transformation; graph A), mean absolute CD4+ T lymphocytes counts/ $\mu$ l and \% CD4+ T lymphocytes in peripheral blood, (graphs B, C). Error bars indicate SEM.

ence in viremia between Mamu-A*01-positive and -negative animals anymore (two-way ANOVA, $\mathrm{p}=0.46$ ).

We examined whether other baseline markers at the onset of tenofovir therapy were predictive of the early virologic response. The magnitude of the early virologic response (i.e., fold decrease of viremia after 1 week of treatment) correlated negatively with baseline viral RNA levels (Pearson $\mathrm{r}=-0.62$, two-tailed $\mathrm{p}=0.03$; Fig. 5B), and negatively with baseline \% CD4+ T lymphocytes (Pearson $\mathrm{r}=-0.84$; two-tailed $\mathrm{p}=0.0007$; Fig. 5C), but not with \% CD8+ T lymphocytes $(\mathrm{p}=0.11$; Fig. 5D). Baseline viral RNA correlated positively with \% CD4+ T lymphocytes (Pearson $\mathrm{r}=$ 0.66; two-tailed $\mathrm{p}=0.019$; Fig. 5A).

\section{Selection of K70E followed by K65R mutation in RT during prolonged tenofovir monotherapy}

For 9 of the 10 animals for which viremia decreased following the onset of tenofovir therapy, the nadir of plasma viral RNA levels was reached after 2 to 4 weeks of treat- 

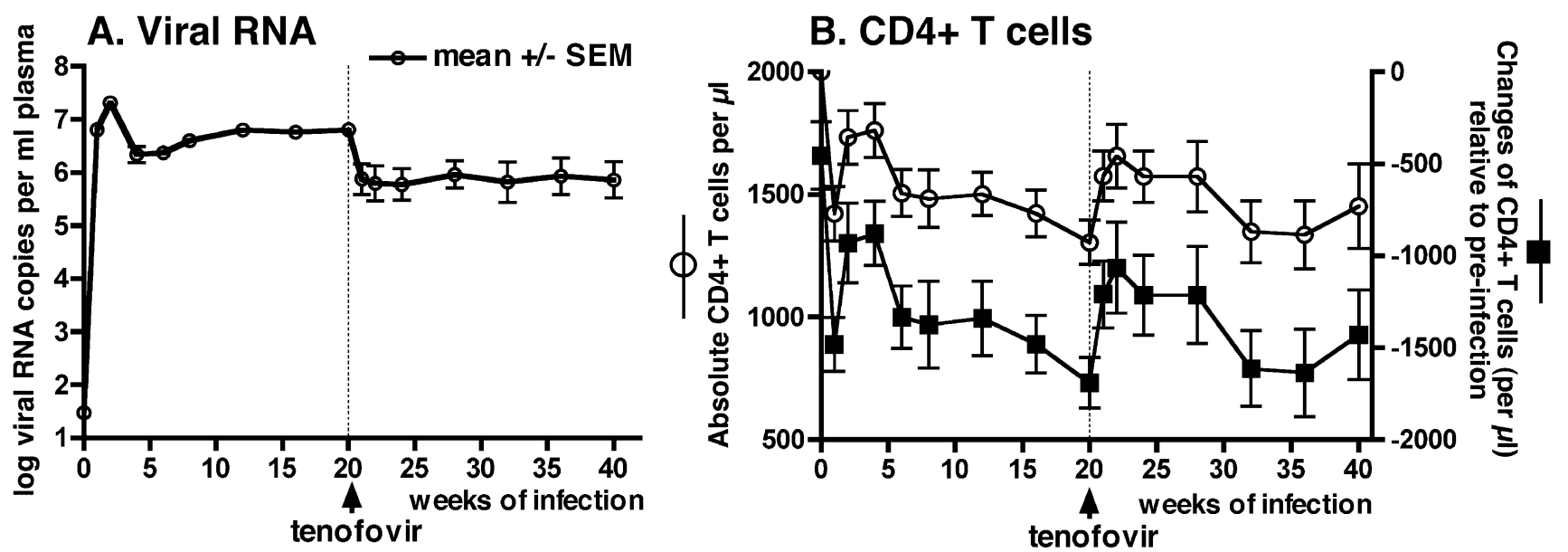

\section{Figure 2}

Effect of tenofovir therapy on mean viral RNA levels and CD4+ T lymphocyte counts. (A) Following tenofovir treatment (vertical dotted line), the average viremia (mean +/- SEM, calculated after log transformation) declined to approximately I log below pre-therapy baseline levels; note that the length of the SEM bars indicates larger variability of viremia after tenofovir therapy than before treatment (as shown in the individual graphs in figure 3). (B). The time course of CD4+CD3+ T lymphocyte counts in peripheral blood of the 12 animals is presented as absolute values (mean +/- SEM) along the left $Y$-axis; in addition, for each individual animal, the change in CD4+ T cell counts relative to its pre-infection value (time zero) was calculated, and the mean +/- SEM of these changes is presented along the right $Y$-axis. Both analyses gave (as expected) identical statistical conclusions.

ment (Fig. 3). Subsequently, there was a partial rebound of viremia, although the average virus levels remained approximately 10-fold below the baseline levels (i.e., at the onset of tenofovir therapy; Fig. 2A). This rebound was associated with the detection of RT mutations that were not detectable prior to tenofovir treatment. Population sequencing of virus isolates from PBMC revealed that the 2 most frequent mutations that emerged sequentially early after tenofovir therapy were a lysine to glutamic acid mutation at codon 70 (K70E; AAA to GAA) followed by the K65R mutation (AAA to AGA)(table 1). Therefore, more sensitive real-time PCR assays were developed to detect and quantify these 2 mutants in viral RNA in sequential plasma samples. While population genotyping of DNA from PBMC-derived virus isolates detected K70E mutants in only 10 animals, the real-time PCR method detected K70E mutants in plasma RNA of all 12 animals within 1 to 4 weeks (median 2 weeks) of tenofovir treatment (Fig. 3, 6). For all 12 animals, the K65R mutation became detectable in plasma viral RNA within 2 to 12 weeks of treatment (median time, 4 weeks). Due to its high sensitivity for detecting low-frequency mutants, the real-time PCR assay detected the K65R mutation prior to its detection by population genotyping in 11 animals (table 1). When both K65R and K70E were detected in plasma viral RNA samples, direct sequencing of the mutation-specific real-time PCR amplicons demonstrated that the 2 mutations were on separate genomes (Fig. 7A). By
12 weeks of treatment, K70E became undetectable prior to or coinciding with the establishment of the K65R mutation in 10 of the 12 animals (Fig. 6).

The K65R mutation resulted in approximately 5-fold reduced in vitro susceptibility to tenofovir (data not shown). Other RT mutations, which were likely compensatory mutations, were also detected in viruses by population sequencing (table 1). Some mutations (e.g. V75I/L, E194K, G196R, L214F) were already present in some viruses obtained prior to tenofovir therapy, and most have previously been described in RT-SHIV isolates obtained from untreated macaques [25,31-33]. The mutations most commonly observed (sometimes transiently) after the detection of K65R included K20R (3 animals), M41L (3 animals), S68G/K/N (12 animals), K70H/N/T/Q (9 animals), W88S (6 animals), Y115F (9 animals), F116W (6 animals), V118I (3 animals), I178M (6 animals), L214F (11 animals), and K219Q/R/E/N/D/H/G (7 animals) (table 1). Sequencing of mutation-specific amplicons revealed that the codon 68 mutations were associated with K65R sequences and not K70E (Fig. 7B); the codon 68 mutations may thus represent mutations that compensate for the replicative fitness cost of K65R, as has been suggested for HIV-1 [5,34]. There was no obvious causative association between these additional RT mutations and the rate of disease progression. Instead, animals that had persistent viremia and longer survival 

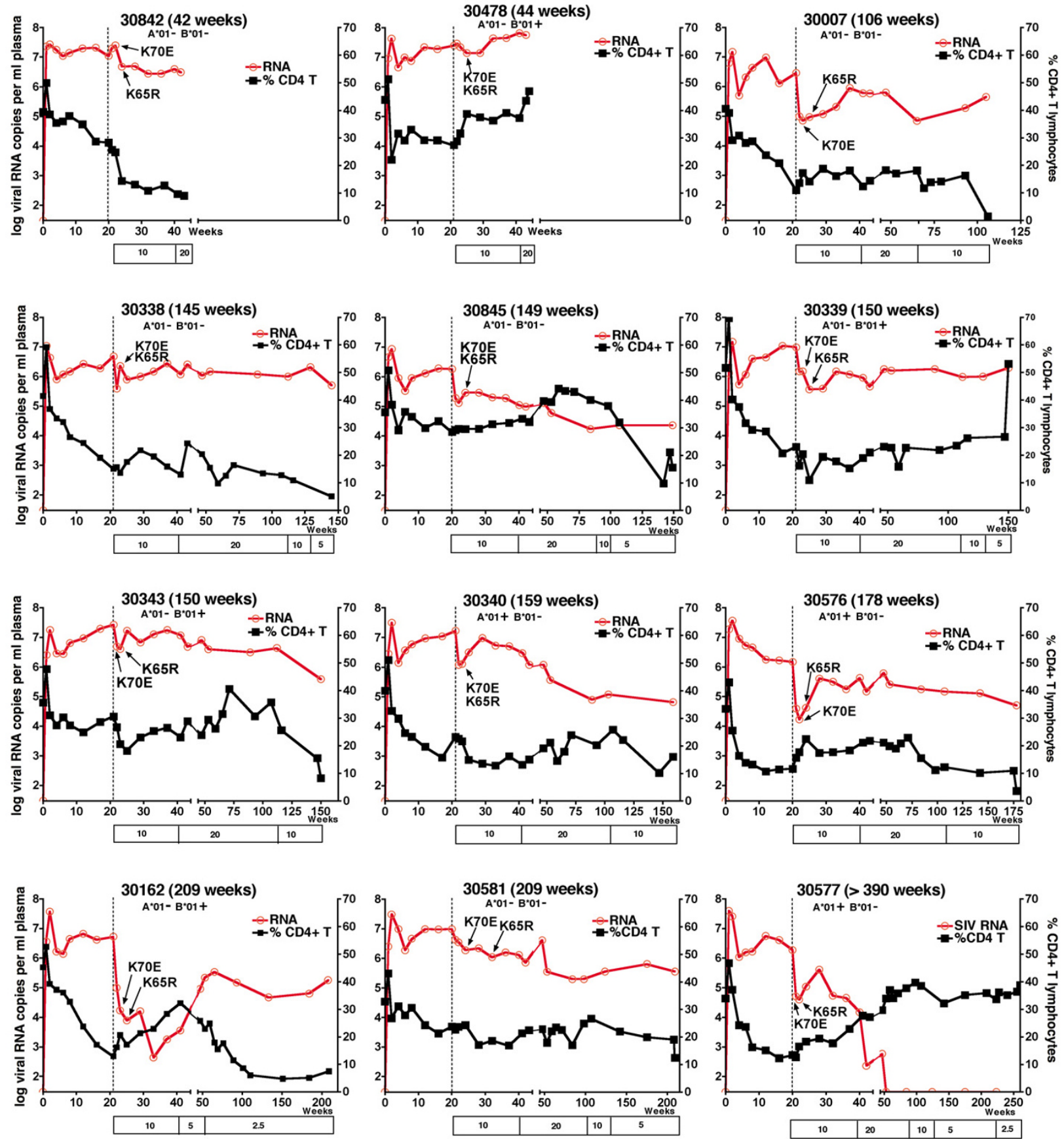

Figure 3

Individual data of plasma viral RNA levels and percentages of CD4+ T lymphocytes. Twelve RT-SHIV infected juvenile macaques were started on tenofovir treatment $(10 \mathrm{mg} / \mathrm{kg}$ subcutaneously, once daily) at approximately 20 weeks of infection (vertical dotted line). Changes in tenofovir dosage regimens (in $\mathrm{mg} / \mathrm{kg}$ ) are indicated in the boxes along the $\mathrm{X}$-axis. Viral RNA levels in plasma (in log-transformed copy number per ml plasma) are presented along the left $Y$-axis, while the \% CD4+ T lymphocytes in peripheral blood is presented along the right $\mathrm{Y}$-axis. The earliest detection of the K70E or K65R mutation in viral RNA in plasma virus by real-time RT-PCR is indicated (see Figure 6 for more details). Animals are arranged according to disease-free survival (which is indicated after each animal number). The presence or absence of the expression of the MHC I alleles Mamu-A*0I and Mamu-B*0I is indicated below each animal number. 

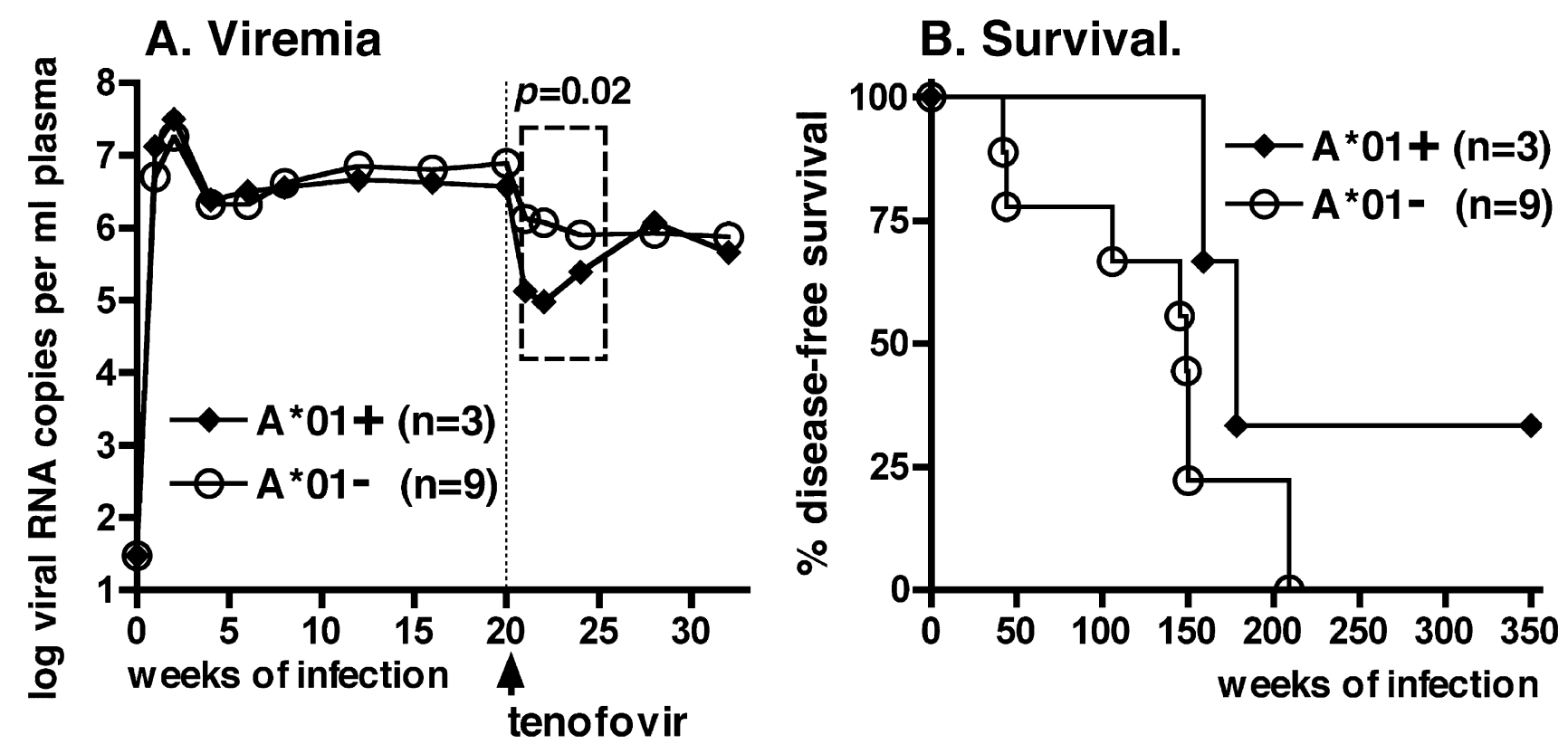

Figure 4

Association of expression of MHC class I allele Mamu-A*0 I with viremia and early virologic response to tenofovir therapy. (A) No significant difference was detected between the 3 Mamu-A*0I-positive and the 9 Mamu-A*0I-negative animals with regard to viremia during the first 20 weeks of infection (two-way ANOVA, $p=0.86$ ) or virus levels at the start of tenofovir treatment (vertical dotted line; two-tailed t-test: $p=0.29$ ). However, during the first 4 weeks following the start of tenofovir treatment (dashed-line box), Mamu-A*0I-positive animals had a bigger reduction in viral RNA levels than Mamu$A * 0 I$-negative animals (two-way ANOVA, $p=0.02$ ); there was no association of the Mamu-B*0I allele with viremia (data not shown). (B) Comparison of disease-free survival following tenofovir treatment revealed no significant difference between the 3 Mamu-A*0 I-positive and 9 negative animals (logrank test, $p=0.14$ ).

accumulated more mutations in RT than animals that had a more rapid disease course; in other words, these additional mutations were not required for a relatively rapid disease course. The tenofovir regimen was increased for most animals at 40 weeks of infection from 10 to $20 \mathrm{mg} /$ $\mathrm{kg}$ to determine if higher drug levels would reduce viremia or select for other patterns of RT mutations that have previously been reported to give higher levels of in vitro resistance to tenofovir, such as T69S-insertion mutations [35]. A pharmacokinetic study showed that the subcutaneous $20 \mathrm{mg} / \mathrm{kg}$ tenofovir regimen in this study gave plasma AUC levels (mean +/- SD: $27.6+/-6.7 \mu \mathrm{g} . \mathrm{h} / \mathrm{ml}$; range 18.7 to $39.2 \mu \mathrm{g} . \mathrm{h} / \mathrm{ml}$ ) slightly higher than those observed in the human trials with intravenous tenofovir dosing $(22.5+/-9.8 \mu \mathrm{g} . \mathrm{h} / \mathrm{ml}$; [30]). This higher dosage regimen did not result in any consistent changes in viremia or any detectable changes in drug resistance patterns (Fig. 3; table 1). Instead, the onset of glucosuria and hypophosphatemia, signs indicative of renal toxicity associated with high-dose tenofovir regimens [36], necessi- tated a reduction of the individual dosage regimens to safer low-dose maintenance regimens (Fig. 3).

The median disease-free survival of the tenofovir-treated animals was 150 weeks ( 3 years). With the caveat that animal numbers per group were low, there was no significant difference in disease-free survival between Mamu$\mathrm{A}^{*} 01$-positive and -negative animals (logrank test, $\mathrm{p}=$ 0.14; Fig. 4B). The two animals (animals 30842 and 30478 ) that did not have a reduction in viremia after the start of tenofovir treatment developed life-threatening immunodeficiency the earliest, at 8-9 months of infection (Fig. 3). Nine chronically treated animals developed fatal disease after 2 to 4 years of infection. For these 11 animals, the gross and histopathologic changes (including lymphoid hyperplasia, lymphoid depletion and opportunistic infections such as Cryptosporidium or Pneumocystis carinii) were characteristic of terminal SIVinduced immunodeficiency. The remaining animal, number 30577, became a long-term survivor with unde- 

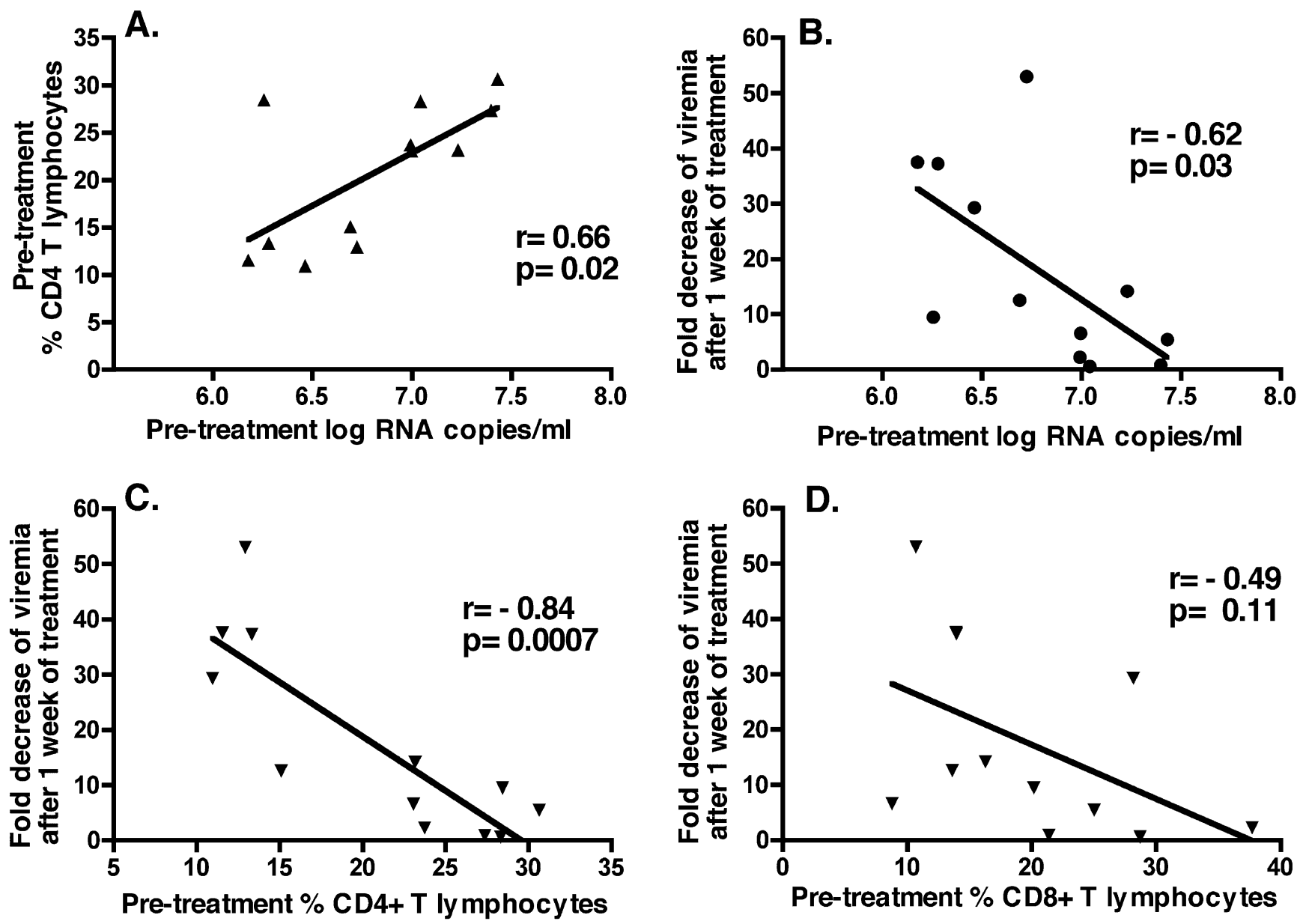

Figure 5

Correlations of baseline viral and immunologic parameters and early virologic response to tenofovir therapy. Pre-treatment values of viral and immunologic parameters are baseline values at the onset of tenofovir treatment (i.e., $\sim 20$ weeks of infection). The early virologic response is expressed as fold decrease of viremia (viral RNA levels in plasma) after I week of tenofovir therapy. Spearman $r$ and two-tailed $p$ values are indicated for each graph. The pre-treatment viral RNA level correlated with the pre-treatment \% CD4+ T lymphocytes (graph A), but did not correlate significantly with percentages of $C D 8+C D 3+T$ lymphocytes or CD20+ B lymphocytes ( $p=0.40$ and 0.12 , respectively; data not shown). The early virologic response had significant correlations $(p \leq 0.05)$ with the pre-treatment viral RNA levels (graph $B$ ), \% CD4+ T lymphocytes (graph C), and percentage and absolute counts of CD20+ B lymphocytes (data not shown). There was no correlation between the early virologic response to tenofovir and baseline lymphocyte counts, the percentages and absolute counts of CD3-CD8+ NK cells in peripheral blood, or SIV-specific IgG titers in plasma (data not shown).

tectable viremia, even though its virus had the K65R mutation in RT. Therefore, this animal is described subsequently in more detail.

\section{The role of both CD8+ cells and tenofovir treatment in suppression of viremia of mutant viruses}

Before the start of treatment, animal 30577 had a viral setpoint of $\sim 10^{6}$ viral RNA copies per ml plasma, and had the expected changes associated with a virulent infection, namely gradual decreases in percentages CD4+ T lymphocyte counts (< 15\%; Fig. 3), absolute CD4+ T lymphocyte counts $(<500$ per $\mu \mathrm{l})$, and CD4+/CD8+ T lymphocyte ratios (ratio $<1$ from week 8 to week 20). Thus, prior to tenofovir treatment, this animal was indistinguishable from the other RT-SHIV infected animals of this study. Following the onset of tenofovir treatment (at 20 weeks of infection), this animal had a rapid reduction in viremia from 1.9 million to 51,000 viral RNA copies/ $\mathrm{ml}$ within one week; these kinetics suggest a half-life of productively infected cells of 1.3 days, very similar to our previous observations in SIVmac251-infected macaques receiving tenofovir treatment during acute viremia [20]. Coinciding with the detection of K70E and K65R mutants (Fig. 3, 8), plasma viremia rebounded from 40,000 (after 
Table I: Mutations in RT detected in virus isolated from RT-SHIV infected macaques.

\begin{tabular}{|c|c|c|c|c|}
\hline Animal number & $\begin{array}{l}\text { Time of Infection } \\
\text { (weeks) }\end{array}$ & Codon 65 mutation & Codon 70 mutation & Other RT mutations \\
\hline \multirow[t]{9}{*}{30007} & $21(T x)$ & - & - & V75L, G196R, M357T/M \\
\hline & 23 & - & - & V75L, GI96R \\
\hline & 25 & - & K70E & G196R, L214F, M357T \\
\hline & 29 & $\mathrm{~K} 65 \mathrm{R} / \mathrm{K}$ & - & G196R, L214F, M357T \\
\hline & 33 & K65R & - & G196R, L2I4F \\
\hline & 41 & K65R & - & S68G, PI50S, E194K, GI96R, 1202V, L214F \\
\hline & 65 & K65R & K70N & S68G, A98G, YII5F \\
\hline & 93 & K65R & $\mathrm{K} 70 \mathrm{H}$ & $\begin{array}{l}\text { V81, S68G, A98G, YII5F, KI54E, AI58P, II59L, GI96R, L2I4F, D2I8E, } \\
\text { K2I9R, H22IP }\end{array}$ \\
\hline & 115 & K65R & $\mathrm{K} 70 \mathrm{H}$ & $\begin{array}{l}\text { V81, K45Q, S68G, A98G, YII5F, VI79I, GI96R, L214F, K2I9R, K275R, } \\
\text { R277K, M357T }\end{array}$ \\
\hline \multirow[t]{9}{*}{30162} & $21(T x)$ & - & - & V75L, G196R, K275R \\
\hline & 25 & - & - & V75L, G196R, K275K/R \\
\hline & 29 & - & - & V75L, G196R, K275R \\
\hline & 33 & - & - & V75L, G196R, K275R \\
\hline & 37 & - & - & K22R, W88S, L214F \\
\hline & 41 & K65R & - & W88S, YII5F, EI94K, L2I4F \\
\hline & 65 & K65R & - & S68S/N, W88S, YIIIF \\
\hline & 93 & K65R & К70T & S68G, K70T, W88S, YII5F, KI54E, AI58P, L2I4F, K219Q \\
\hline & 209 & K65R & К70T & $\begin{array}{l}\text { S68G, K70T, W88S, YII5F, TI39A, II78M, L2I4F, H22IY, K275R, R277K, } \\
\text { M357N }\end{array}$ \\
\hline \multirow[t]{6}{*}{30478} & $21(T x)$ & - & - & V75L, H208L, L2I4F \\
\hline & 25 & - & - & V75V/L, H208L. L214F \\
\hline & 29 & - & $\mathrm{K} 70 \mathrm{E} / \mathrm{K}$ & H208L, L2I4F \\
\hline & 33 & $\mathrm{~K} 65 \mathrm{~K} / \mathrm{R}$ & $\mathrm{K} 70 \mathrm{E} / \mathrm{Q} / \mathrm{K}$ & G196R, L2I4F \\
\hline & 37 & K65R & - & S68N, G196R, L2I4F \\
\hline & 41 & K65R & - & S68N, G196R, L214F \\
\hline \multirow[t]{10}{*}{30338} & $21(T x)$ & - & - & GI96R \\
\hline & 22 & - & - & V75L, G196R, L2I4F, K275R, M357T \\
\hline & 23 & - & - & V2II, V75L, G196R, L2I4F \\
\hline & 25 & - & K70K/E & V75L, G196R, L214F \\
\hline & 29 & K65R & - & G196R, L214F, M357T \\
\hline & 33 & K65R & - & G196R, L214F, K275R, M357T \\
\hline & 41 & K65R & - & S68N, YII5F, GI96R, L2I4F \\
\hline & 59 & K65R & K70Q & S68N, YII5F \\
\hline & 89 & K65R & K70Q & K20R, YII5F, KI54Q, Al58T, II78M, E194K, G196R, L2I4F, K219Q \\
\hline & 145 & K65R & K70Q & $\begin{array}{l}\text { V81, K20R, M4IL, S68G, W88S, YII5F, FII6W, II78M, G196R, L2I4F, } \\
\text { H22IY, K275R, R277K, P294Q, M357T }\end{array}$ \\
\hline \multirow[t]{8}{*}{30339} & $21(T x)$ & - & - & EI94K, GI96R, \\
\hline & 25 & WT & - & W88S, G196R, L2I4F, M357T \\
\hline & 29 & K65R & - & W88S, G196R, K275R, R277K, M357T \\
\hline & 33 & K65R & - & S68R, W88S, G196R, L214F, K275R \\
\hline & 41 & K65R & - & S68K, W88S, G196R, R199M, K219E \\
\hline & 59 & K65R & - & S68K, W88S, Y1I5F, K219E \\
\hline & 89 & K65R & - & K22R, K64R, S68K, W88S, YIIIFF, K154Q, AI58P, II78M, GI96R \\
\hline & 150 & K65R & - & $\begin{array}{l}\text { T39A, K45Q, K64R, S68K, W88S, YII5F, II78M, V195L, G196K, K219G, } \\
\text { H22IY, K275R, R277K, M357T }\end{array}$ \\
\hline \multirow[t]{9}{*}{30340} & $21(T x)$ & - & - & V75L, EI94K, G196R, \\
\hline & 22 & - & - & V75L, GI96R \\
\hline & 23 & - & $\mathrm{K} 70 \mathrm{~K} / \mathrm{E}$ & GI96R \\
\hline & 25 & - & $\mathrm{K} 70 \mathrm{~K} / \mathrm{E}$ & G196R \\
\hline & 29 & K65R & - & G196R \\
\hline & 33 & K65R & - & GI96R, L2I4F \\
\hline & 41 & K65R & - & S68G, YII5F, VII8I, E194K, GI96R, RI99I \\
\hline & 89 & K65R & - & K20R, S68G, W88S, YII5F, G196R, RI99I, L2I4F, H22IY \\
\hline & 159 & K65R & K70Q & S68K, W88S, YII5F, FII6W, GI96R, L2I4F, H22IY, S25IN, R277K, M357T \\
\hline 30343 & $21(\mathrm{Tx})$ & - & - & G196R, K219N \\
\hline
\end{tabular}


Table I: Mutations in RT detected in virus isolated from RT-SHIV infected macaques. (Continued)

\begin{tabular}{|c|c|c|c|c|}
\hline & 22 & - & - & G196R, K219N, K275R, M357T \\
\hline & 23 & - & - & G196R, K275R, M357T \\
\hline & 25 & $\mathrm{~K} 65 \mathrm{~K} / \mathrm{R}$ & K70K/E & G196R, K275R, M357T \\
\hline & 41 & K65R & - & S68N, GI96R \\
\hline & 59 & K65R & - & S68N, YII5F, Y18IC, K2I9N/D \\
\hline & 89 & K65R & - & S68N, W88S, YII5F, FII6W, G196R, K219H \\
\hline & 150 & K65R & $\mathrm{K} 70 \mathrm{H}$ & $\begin{array}{l}\text { M4IL, S68K, W88S, YIIIFF, FII6W, VII8I, II78M, G196R, K219H, K275R, } \\
\text { R277K, M357T }\end{array}$ \\
\hline \multirow[t]{11}{*}{30576} & $20(T x)$ & - & - & V75I, E194K, G196R, L210V, L214F \\
\hline & 21 & - & - & V75L, G196R, L214F, K275R, G359S \\
\hline & 22 & - & $\mathrm{K} 70 \mathrm{E} / \mathrm{K}$ & G196R, L2I4F \\
\hline & 24 & - & $\mathrm{K} 70 \mathrm{E} / \mathrm{K}$ & G196R, E203G, L2I4F \\
\hline & 28 & - & $\mathrm{K} 70 \mathrm{E} / \mathrm{K}$ & G196R, L2I4F, M357T \\
\hline & 32 & K65R & & S68N, G196R, L214F, K275R, M357T \\
\hline & 36 & K65R & & S68N, GI96R, L214F, M357T \\
\hline & 40 & K65R & - & S68N, II95T, G196R, L214F \\
\hline & 53 & K65R & - & S68N, YIII5F \\
\hline & 84 & K65R & K70N & V8I, S68G, YII5F, FII6W, Q145H, PI50S, GI96R, H208Q, L2I4F \\
\hline & 178 & K65R & $\mathrm{K} 70 \mathrm{H}$ & $\begin{array}{l}\text { V7I, K45Q, S68G, YIIIF, FII6W, RI72S, KI73Q, II78M, GI96R, I202V, } \\
\text { L2I4F, K2I9R, K275R, R277K, M357T }\end{array}$ \\
\hline \multirow[t]{8}{*}{30577} & $20(T x)$ & - & - & El94K, GI96R \\
\hline & 22 & - & - & V75L, G196R, L214F \\
\hline & 24 & - & $\mathrm{K} 70 \mathrm{E} / \mathrm{K}$ & II78M, G196R, L214F \\
\hline & 28 & $\mathrm{~K} 65 \mathrm{~K} / \mathrm{R}$ & $\mathrm{K} 70 \mathrm{E} / \mathrm{K}$ & II78M, GI96R \\
\hline & 40 & K65R & - & K20R, S68N, EI94K, G196R, RI99K, L2I0V, L2I4F \\
\hline & 47 & K65R & - & S68N, GI96R \\
\hline & 265 (no CD8) & K65R & - & K20R, S68N, G196R, L214F, Q248N \\
\hline & 296 (no Tx) & K65R & - & K20R, S68N, G196R, L2I4F, Q248N \\
\hline \multirow[t]{9}{*}{30581} & $20(T x)$ & - & - & V75I, EI94K, GI96R, \\
\hline & 22 & - & - & V75L, G196R, L214L/F \\
\hline & 24 & - & $\mathrm{K} 70 \mathrm{~K} / \mathrm{E}$ & V75L, GI96R \\
\hline & 28 & - & K70E & GI96R, M357T \\
\hline & 32 & K65R & - & G196R, L2I4F, M357T \\
\hline & 40 & K65R & - & S68G, G196R, L214F \\
\hline & 53 & K65R & K70T & S68G, FII6W \\
\hline & 84 & K65R & K70T & S68G, A98G, FII6W, PI50S, II59V, RI72I, VI79G, Q222L \\
\hline & 209 & K65R & K70T & $\begin{array}{l}\text { E40Q, K45Q, S68G, T691, A98G, FII6W, II78M, G196R, K219R, K275R, } \\
\text { R277K, M357S }\end{array}$ \\
\hline \multirow[t]{7}{*}{30842} & $20(T x)$ & - & - & V75L, EI94K, GI96R, \\
\hline & 22 & - & - & V75L, G196R, L214F \\
\hline & 24 & - & K70E & G196R, L2I4F \\
\hline & 28 & $\mathrm{~K} 65 \mathrm{R} / \mathrm{K}$ & - & G196R, L2I4F \\
\hline & 32 & K65R & - & S68N, G196R, L214F, N218E, M357T \\
\hline & 40 & K65R & - & E194K, G196R, L2I4F \\
\hline & 42 & K65R & - & YII5F, Y18IC, K219E \\
\hline \multirow[t]{11}{*}{30845} & $20(T x)$ & - & - & V75I, EI69K, EI94K, GI96R, \\
\hline & 21 & - & - & V75V/L, GI96R \\
\hline & 22 & - & - & T69N/T, W88S, G196R, L2I4F \\
\hline & 24 & - & $\mathrm{K} 70 \mathrm{~K} / \mathrm{E}$ & G196R, K275R \\
\hline & 28 & $\mathrm{~K} 65 \mathrm{~K} / \mathrm{R}$ & K70E & GI96R \\
\hline & 32 & K65R & & G196R, L214F, K275R, M357T \\
\hline & 36 & K65R & & S68G, W88S, G196R, M357T \\
\hline & 40 & K65R & - & S68G, W88S, EI94K, GI96R, L2I4F \\
\hline & 53 & K65R & - & S68G, W88S, YII5F \\
\hline & 84 & K65R & $\mathrm{K} 70 \mathrm{~N}$ & S68G, W88S, A98G, YII5F, PI50S, DI77N \\
\hline & 149 & K65R & K70N & $\begin{array}{l}\text { KIIN, V2II, K22R, M4IL, S68G, W88S, YIII5F, FII6W, VII8I, H22IY, } \\
\text { V245M, K275R, R277K, I275R, M357T }\end{array}$ \\
\hline
\end{tabular}

All data were obtained from PBMC isolates by population sequencing methods. (Tx) indicates the start of tenofovir therapy. (no CD8) and (no Tx) indicate the viral rebound during CD8+ cell depletion experiment and tenofovir withdrawal experiment of animal 30577, respectively. 

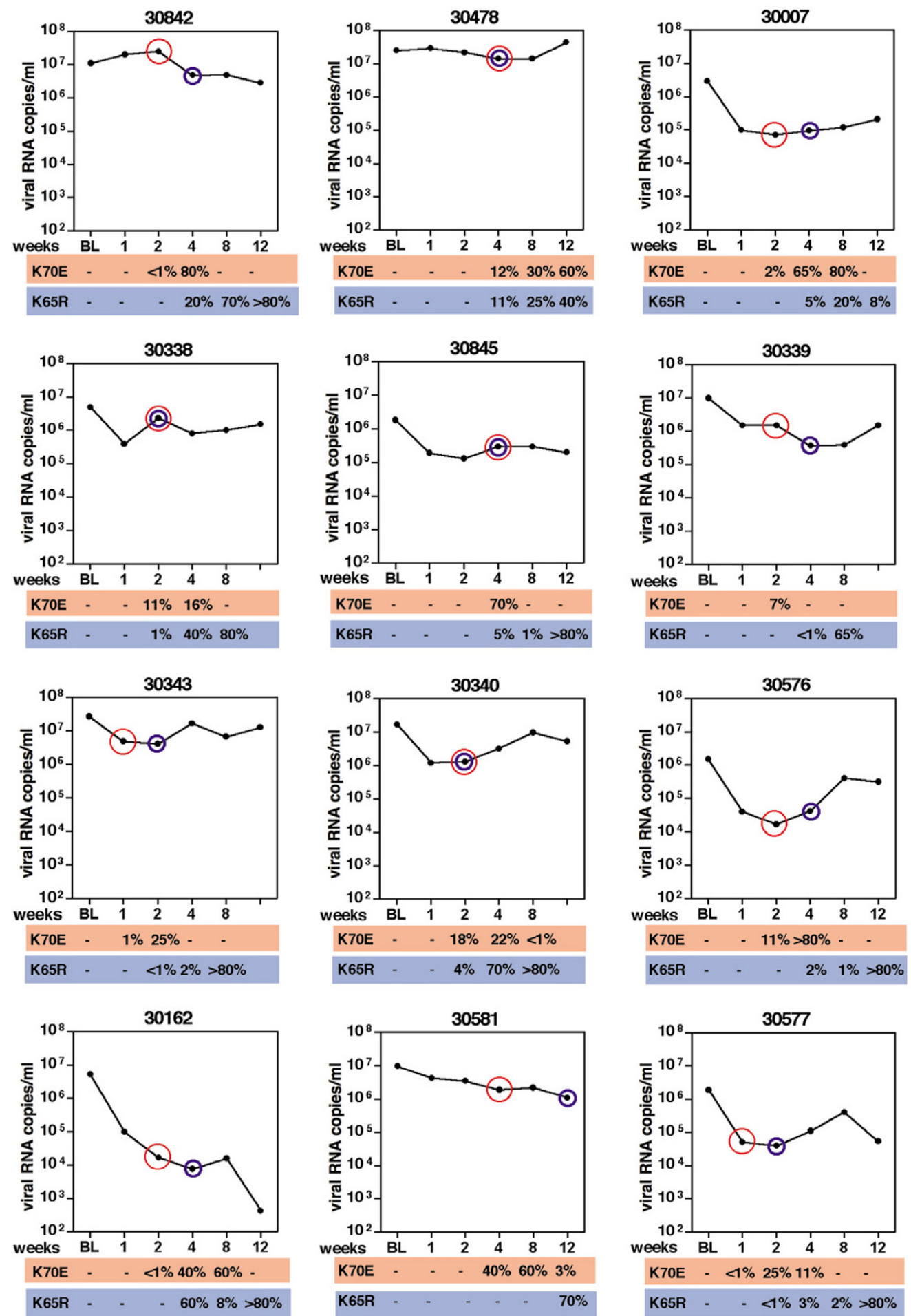

\section{Figure 6}

Kinetics of K70E and K65R RT mutants during tenofovir therapy. Twelve RT-SHIV infected macaques were started on tenofovir treatment 5 months after infection. Real-time PCR technology was used to quantitate K65R and K70E RT mutants in plasma samples; values are expressed as percentage of total viral RNA copy number. At the onset of tenofovir therapy (i.e, baseline, BL), no K65R and K70E virus could be detected. The red and blue circles indicate the first detection of K70E and $\mathrm{K} 65 \mathrm{R}$, respectively; weeks indicate weeks of tenofovir treatment. 


\section{A. Segregation of $\mathrm{K} 65 \mathrm{R}$ and $\mathrm{K} 70 \mathrm{E}$} Population

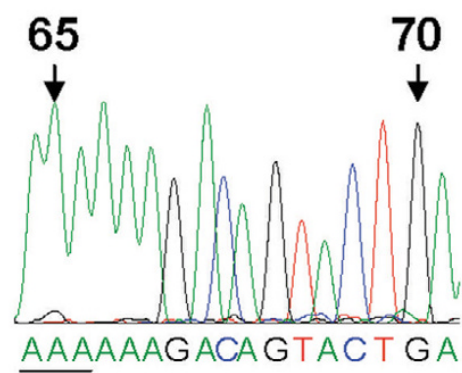

65R amplicon

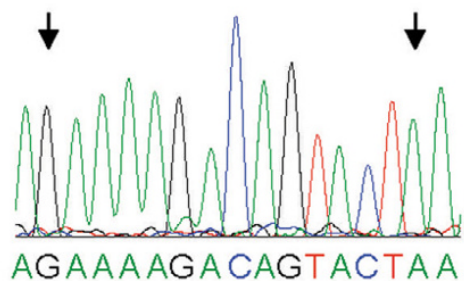

70E amplicon

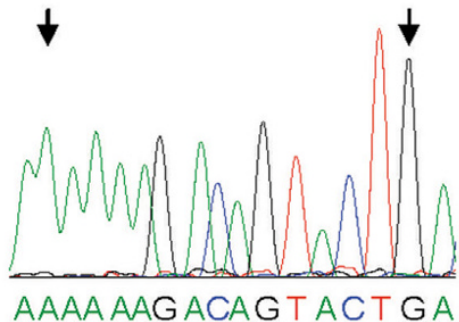

\section{B. Linkage of codon 68 mutations to K65R}
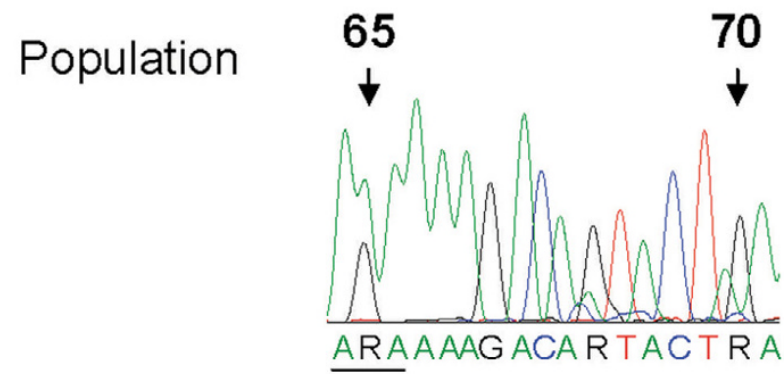

65R amplicon

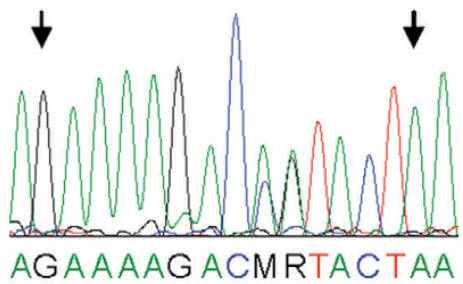

70E amplicon

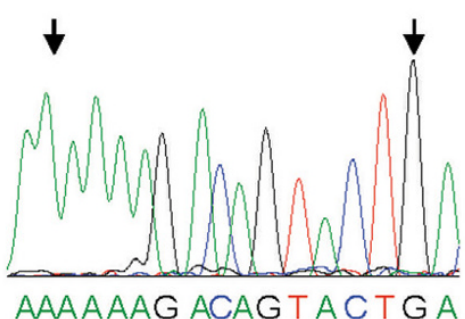

\section{Figure 7}

Segregation of K65R and K70E mutations, and linkage of codon 68 mutations with K65R. Plasma viral RNA samples in which real-time PCR assays detected both K65R and K70E mutations were analyzed further; representative samples are shown. Panel A: animal 30007, week 8 of tenofovir treatment (see Figure 6). Population sequencing revealed a mixture of wildtype and mutant variants at both codons 65 and 70 (top graph); the bar indicates the codon reading frame. The selective amplification of virus sequences containing $65 \mathrm{R}$ or $70 \mathrm{E}$ by real-time PCR allowed for their enrichment from the virus background quasispecies. Direct sequencing of the mutation-specific amplicons revealed that the 65R amplicon (AGA, arginine) had wildtype sequence at codon 70 (AAA, lysine; middle graph), while the 70E amplicon (GAA, glutamic acid) had wild-type at codon 65 (lysine, AAA; bottom graph). Thus, the K65R and K70E mutations were on separate viral genomes. Panel B: animal 30478, week 12 of tenofovir treatment. The mutation-specific amplicons from this specimen also exhibited segregation of K65R and $\mathrm{K} 70 \mathrm{E}$. The sequence of the $65 \mathrm{R}$ amplicon demonstrated mutations at codon 68 (middle graph), while the $70 \mathrm{E}$ amplicon had wild-type sequence (AGT, serine) at codon 68 (bottom graph). The presence of mixtures is indicated (M is $A$ or $C$; $R$ is $A$ or $\mathrm{G).}$

2 weeks of treatment) to 410,000 copies per $\mathrm{ml}$ at 8 weeks of treatment (i.e., 28 weeks of infection), but then gradually declined again and became undetectable $(<30$ viral RNA copies/ml) from 53 weeks of infection onwards (i.e., 33 weeks of tenofovir treatment; Fig. 8). During continued tenofovir treatment, there was a gradual increase of CD4+ T lymphocyte values to normal pre-infection levels (percentage of CD4+ T lymphocytes: 30-39\%; CD4+/ CD8+ T-cell ratio 1.25-1.75; absolute CD4+ T lymphocyte counts: $\geq 700$ per $\mu$; Fig. 3, 8).

Similarly to our previous studies in tenofovir-treated SIVmac251-infected macaques [20], we investigated if this suppressed viremia of K65R virus in animal 30577 during 


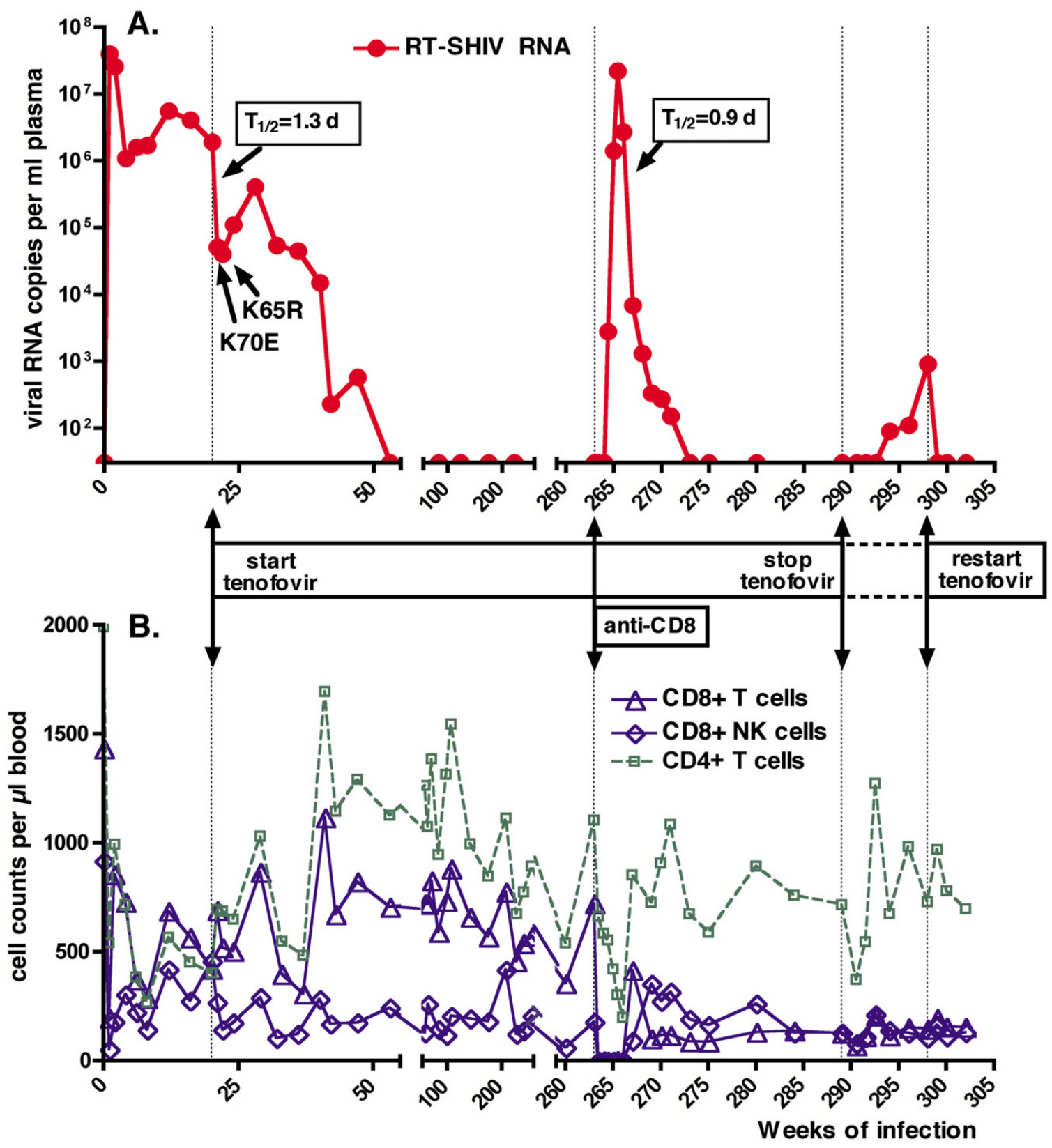

Figure 8

Importance of both CD8+ cell-mediated immune responses and continuous tenofovir treatment in RT-SHIV infected animal 30577. As indicated in Figure 3, animal 30577 was inoculated with RT-SHIV (time zero). Panel A and B represent viral RNA levels in plasma, and cell counts in peripheral blood (as measured by flow cytometry), respectively. Tenofovir treatment was started at 20 weeks of infection (vertical dotted line), resulting in an initial rapid 47-fold reduction of viremia (with estimated half-life of productively infected cells of I.3 days). Despite an initial rebound associated with emergence of K70E followed by K65R viral mutants (table I; Fig. 6), viremia became undetectable at 55 weeks of infection. At 264 weeks of infection, CD8+ cells were depleted using administration of 3 doses of cM-T807, while tenofovir treatment was continued (at a maintenance regimen of $2.5 \mathrm{mg} / \mathrm{kg}$ once daily). After a $\sim 6 \mathrm{log}$ increase in viremia (consisting of K65R virus), virus levels decreased rapidly (with estimated half-life of productively infected cells of 0.9 days) as soon as CD8+ cells started to return. At 289 weeks of infection, tenofovir treatment was interrupted for 9 weeks, and when viremia increased, restarted at the same regimen. The increased viremia during both experimental manipulations demonstrate that both CD8+ cells and continued tenofovir therapy were required for optimal suppression of viremia. 
prolonged tenofovir treatment was due to (i) a replication-impaired phenotype of the K65R mutant in this animal, (ii) strong CD8+ cell-mediated antiviral immune responses, and/or (iii) residual antiviral activity of the tenofovir regimen. Accordingly, 2 sequential experiments were performed, in which either CD8+ cells or tenofovir treatment were removed. In the first experiment, CD8+ cells were temporarily depleted via administration of 3 doses of the anti-CD8 antibody cM-T807 at 263 weeks of infection ( $\sim 5$ years of infection, and 4 years of undetectable viremia). Tenofovir treatment was continued at a stable maintenance regimen $(2.5 \mathrm{mg} / \mathrm{kg}$ once daily, subcutaneously) during this period. Following the first dose of cM-T807, CD8+ T cells and NK cells were undetectable or very low $(<1 \%$ of lymphocytes; $<5$ cells per $\mu$ l) in peripheral blood for 3 weeks. Viral RNA levels became again detectable in plasma 10 days after the first cM-T807 injection, and peaked to 22 million RNA copies $/ \mathrm{ml}$ on day 17 (Fig. 8). This dramatic increase in viral RNA levels in plasma was accompanied by an increase in infectious virus titers in PBMC, from undetectable $(<1)$ to 3,160 TCID $_{50}$ per million PBMC on day 17 (data not shown). Real-time RT-PCR revealed that the plasma viral RNA at peak viremia consisted exclusively of K65R viral mutants, with no detection of the K70E mutation or wild-type sequence; this plasma viral RNA had also the $\mathrm{S} 68 \mathrm{~N}$ and G196R mutations; virus isolated from PBMC at peak viremia also had the expected K65R mutation, with relatively few other RT mutations compared to virus isolated 4 years earlier (table 1 ). When the CD8+ T lymphocytes and NK cells returned, plasma viral RNA levels and cellassociated infectious virus levels declined rapidly to undetectable baseline levels ( $<30$ RNA copies per ml plasma and $<1 \mathrm{TCID}_{50}$ per million PBMC, respectively). The initial phase of very rapid decline of viral RNA levels during the return of CD8+ cells indicates a half-life of productively infected cells of 0.9 days, suggesting high antiviral potency of the returning CD8+ cells (Fig. 8). This transient rebound in viremia following CD8+ cell depletion was associated with a progressive decrease in CD4+ T lymphocyte counts (nadir of 199 cells per $\mu \mathrm{l}$ ), which returned to normal levels ( $>500$ per $\mu \mathrm{l}$ ) upon the reduction of viremia to undetectable levels (Fig. 8).

To determine if continued tenofovir treatment was required to maintain undetectable viremia in animal 30577 , tenofovir treatment was interrupted at 289 weeks ( 5.5 years) of RT-SHIV infection. Five weeks later, virus could be isolated again from PBMC, and this virus had the K65R and the same other RT mutations (including S68N) that were also detected during the viral rebound of the CD8+ depletion experiment (table 1). Starting 5 weeks after tenofovir withdrawal, viral RNA levels in plasma also became detectable again and increased slowly (Fig. 8). Real-time PCR performed on the plasma sample collected
9 weeks after tenofovir withdrawal (which had a viral load of 910 RNA copies per ml) revealed K70E but no K65R. Further sequencing of the plasma RNA revealed that this K70E virus had also G196R, but not S68N; although it did not have $\mathrm{I} 178 \mathrm{M}$, this $\mathrm{K} 70 \mathrm{E}$ virus therefore resembled the virus that was detected early after the start of tenofovir treatment (see table 1, week 24 isolate). Nine weeks after tenofovir withdrawal (when viremia was 910 RNA copies/ $\mathrm{ml}$ ), tenofovir was restarted at the same regimen; both the PBMC-associated infectious virus levels and the plasma viral RNA levels returned to persistently undetectable levels $(<30$ copies $/ \mathrm{ml}$ ) within one week of treatment (Fig. 8). Thus, continued tenofovir therapy was required to maintain optimal suppression of K65R and K70E viremia in this animal.

\section{Discussion}

The current report provides further insights into the many aspects of chronic tenofovir therapy, including the sequential emergence and implications of K70E and K65R viral mutants. These data are important and timely, considering (i) the increased use of tenofovir in HAART regimens, and (ii) the ongoing clinical trials which investigate if chronic administration of tenofovir can protect highrisk groups against HIV infection, particularly since no prophylactic strategy is likely to be $100 \%$ effective [37]. The present data largely confirm the observations made previously with tenofovir in the SIVmac251 model [20], but the use of RT-SHIV led to novel findings, such as the transient detection of K70E viral mutants early after the start of tenofovir therapy. The advantage of an animal model is that it allows the control of many variables and experimental procedures (such as monotherapy and CD8+ cell depletions) that enable the study of mechanisms that would otherwise be difficult to unravel, and that are relevant to the clinical use of tenofovir-containing regimens in HIV-1 infected humans.

In the current study, intravenous inoculation of the first group of macaques with a high dose of RT-SHIV led to persistent viremia with set-point of $10^{6}$ to $10^{7}$ viral RNA copies per ml plasma, higher than that observed in some previous studies that used a lower virus inoculum $[26,28,31]$. Sequential in vivo passages of RT-SHIV did not lead to detectable changes in virulence, as determined by viremia, and CD4+ and CD8+ T lymphocyte counts. It is plausible that after the high-dose intravenous inoculation, the potential virulence was already maximized, as viremia levels were similar to those commonly observed with the parental SIVmac239 virus [38,39].

Others have reported that when RT-SHIV infected macaques were started on short-term tenofovir treatment (30 $\mathrm{mg} / \mathrm{kg}$, subcutaneously SID) either during acute viremia or during chronic infection (when viral set-points 
were $10^{4}$ to $10^{6} \mathrm{RNA}$ copies $/ \mathrm{ml}$ ), viremia was rapidly reduced in all animals $[26,29]$. In the current study, the early virologic response to tenofovir was more variable, possibly because of the lower tenofovir dose $(10 \mathrm{mg} / \mathrm{kg})$ and the higher pre-therapy viral RNA set-points $\left(\sim 10^{6}\right.$ to $10^{7} \mathrm{RNA}$ copies $/ \mathrm{ml}$ ). In the present study, a higher pretherapy viral RNA set-point (an indirect measure of weaker antiviral immune responses at the onset of treatment) correlated with a reduced early virologic response to tenofovir.

The expression of the MHC Class I allele Mamu-A*01 has previously been associated with a better immunologic control of the parental SIVmac239 virus, and antiviral CD8+ CTL responses directed against Mamu-A*01restricted epitopes (including in Gag and Tat) were found to be dominant during SIVmac239 infection [40,41]. In the current RT-SHIV study, which had the limitation of small animal groups, there was no difference in viremia between Mamu-A*01 positive and -negative animals before the onset of tenofovir therapy. However, animals which expressed the Mamu- $\mathrm{A}^{*} 01$ allele had a more pronounced drop in viremia during the first 4 weeks of tenofovir therapy than Mamu- $A * 01$-negative animals. This observation suggests that any role of Mamu-A*01dependent antiviral immune responses in attempting to control viremia was transiently unmasked or rescued by the concomitant tenofovir treatment. These findings are consistent with previous observations (including from studies that used CD8+ cell depletion) that demonstrated that the early virologic response to tenofovir and other drugs in SIV and env-SHIV-infected macaques is highly dependent on the strength of antiviral immune responses $[20,22,42,43]$. Evidence from human trials also suggests a role of the immune system in determining the efficacy of drug treatment, as lower baseline viral RNA levels, a better status of the immune system, and certain MHC class II genotypes are predictive of a faster and/or more sustained response to HAART [44-49]. In HIV-1 infected humans, the reduction in viral RNA levels following the start of tenofovir therapy was larger and faster in treatment-naive patients than in treatment-experienced patients who generally had lower CD4+ T cell counts [50-52]. In the current study with macaques, RT-SHIV infection led to a reduction of CD4+ cell counts and percentages in peripheral blood, but an unexpected finding was that lower pre-therapy baseline values of percentage CD4+ T cells were associated with lower RNA levels, and a better early virologic response to tenofovir. While our study was not designed to unravel the mechanisms linking viremia and CD4+ T cell counts in peripheral blood, this observation mainly highlights that $\mathrm{CD} 4+\mathrm{T}$ cell numbers in the peripheral blood of the macaques were not a very reliable marker of immunocompetence at this intermediate stage of RTSHIV infection.
When RT-SHIV infected macaques were started on tenofovir, there was a rapid selection for viral mutants with a K70E RT mutation. The K70E RT mutants were subsequently replaced by K65R RT mutants. Similarly to observations with HIV-1 $[53,54]$, when K70E and K65R RTSHIV mutants were both detected in plasma, these 2 mutations were found on separate viral genomes. The K70E mutation has previously been described in HIV-1 after selection pressure with adefovir in vitro and in vivo $[55,56]$. The K70E mutation has only been described in a few cases of tenofovir-treated HIV-1 infected persons, although it is possible that a more systematic investigation of early samples following tenofovir therapy may reveal a higher frequency $[54,57,58]$. Because the regimen of these HIV-1 infected persons included also other RT inhibitors (e.g., abacavir and lamivudine; [54,57]), the detection of K70E virus in macaques during tenofovir monotherapy is the first evidence that tenofovir can select directly for this K70E mutation in vivo. In the current macaque study, it is possible that a higher precursor mutation frequency at codon 70 (but still below the $0.2 \%$ detection limit in the baseline samples) may have predisposed for selective outgrowth of first variants with the K70E mutation which, in vitro, confers only a relatively minor fitness cost and minimal resistance to tenofovir (ranging from no effect to $\leq 2$-fold reduced susceptibility) $[2,56,59]$. These K70E mutants were then rapidly replaced by K65R mutants which in the absence of drug are more replication-impaired in vitro than K70E mutants, but in the presence of tenofovir could outgrow K70E mutants due to a slightly higher level ( $\sim 4-5$ fold) of in vitro resistance to tenofovir $[56,60]$. This replacement of variants based on replicative capacity would be similar to observations in lamivudine-treated patients, where differences in pre-therapy frequencies of codon 184 mutants also appear to explain the transient detection of M184I mutants, which are then replaced by the more fit M $184 \mathrm{~V}$ mutants [61]. While previous studies in macaques used usually higher tenofovir regimens $(20-30 \mathrm{mg} / \mathrm{kg}$ subcutaneously SID; [20,62-64]), it is unclear if the $10 \mathrm{mg} / \mathrm{kg}$ tenofovir regimen of the current study may also have contributed to a transient outgrowth of K70E mutants that were subsequently, when intracellular drug levels built up to steady-state levels, replaced by the more resistant K65R mutants.

The emergence of K65R RT-SHIV mutants during tenofovir treatment was accompanied by an accumulation of other RT mutations, believed to be compensatory mutations that improve the replicative capacity of $\mathrm{K} 65 \mathrm{R}$ virus. Many of these mutations have been described previously with or without K65R in HIV-1 infected persons receiving tenofovir-containing or other HAART regimens, and some (such as $\mathrm{M} 41 \mathrm{~L}$ ) have been reported to contribute to a 
reduced virologic response to tenofovir when in combination with other RT mutations $[5,8,14,34,59,65,66]$.

The clinical implications of the K70E and K65R RT-SHIV mutants were similar to those reported previously for K65R SIVmac251 mutants $[19,20,22]$. In the current RTSHIV study, because treatment was initiated after 20 weeks of persistently high viremia, the immune system was already compromised. In such situation, for the majority of animals, CD8+ cell-mediated immune responses were not sufficient to assist in suppressing viremia to very low levels especially once the RT mutants emerged. Following the emergence of such viral mutants, plasma viremia of most animals increased and stabilized to a level on average 10-fold below pre-therapy baseline values, indicating some residual therapeutic benefit. This lower viremia may be due to a combination of several factors, including decreased replicative capacity of the K65R mutants (especially of the early mutants, prior to the accumulation of presumed compensatory mutations), some residual antiviral effects of the tenofovir regimen, and/or antiviral immune responses (see further). These findings are consistent with observations in tenofovir-treated humans, where the detection of $\mathrm{K} 65 \mathrm{R}$ is not always associated with a virologic rebound $[1,5]$, and the detection of the K65R mutation with a virologic rebound was most likely in patients with high baseline RNA levels and low CD4+ cell counts $[3,6,9,67]$. The findings of a $~ 10$-fold reduced viremia in most K65R RT-SHIV infected animals during continued tenofovir monotherapy are reminiscent of observations in people who are infected with M184V mutant HIV-1, and for whom continuation of lamivudine monotherapy is associated with a $\sim 2$ - to 4 -fold reduction in viremia and clinical benefits [68-73]. In contrast, for some other drugs (such as nevirapine), the emergence of viral mutants has been associated with a rebound of viremia to pre-therapy levels [74].

While 11 of the 12 animals maintained persistent viremia and eventually developed disease, animal 30577 was an exception. Further research is needed to determine which host and/or viral factors (e.g., unique genotypes) may have been responsible for this different outcome, as animal 30577 was initially indistinguishable from the other animals based on our limited panel of pre- and early posttherapy markers (virus levels, CD4+ and CD8+ lymphocyte numbers, and emergence of RT mutations). Animal 30577 first had a rapid 47-fold reduction in viremia within 2 weeks of treatment but then had a 10 -fold increase in viremia above nadir levels by 8 weeks of treatment, that was associated with the emergence of K70E followed by K65R viral mutants. Several human studies in which tenofovir-containing HAART regimens were initiated in antiretroviral-naïve patients used virologic criteria ( $<2 \log$ reduction in viral RNA by week 8 ; rebound of $\geq$
0.5-1 log RNA copies/ml above nadir $[6,11,67])$ according to which this viral RNA pattern in animal 30577 would have been classified as a "virologic non-response" or "treatment failure", and tenofovir treatment would have been withdrawn. However, despite the initial viral RNA rebound in this macaque, continued tenofovir treatment led to a gradual decrease of viremia to undetectable levels after 8 months of therapy. Thus, our data suggest that further studies (including retrospective analysis of already available samples) are warranted to investigate the potential clinical benefits of continued tenofovir therapy in HIV-1 infected patients even after a partial rebound with the detection of $\mathrm{K} 65 \mathrm{R}$ viral mutants, as it is possible that some individuals may eventually suppress viremia again [22].

The CD8+ cell depletion experiment demonstrated that the reduced viremia in tenofovir-treated animal 30577 was mediated largely by CD8 + cells, because removal of CD8 + cells caused a transient $\sim 1$ million-fold increase of K65R viremia, to peak levels similar to those observed during acute viremia with wild-type RT-SHIV (Fig. 3, 8). Because a stable tenofovir treatment regimen was continued during the CD8+ cell depletion experiment, this dramatic increase in K65R viremia, which was associated with a reduction in $\mathrm{CD} 4+\mathrm{T}$ lymphocyte counts, indicates that in the absence of CD8+ cells, tenofovir treatment alone had insufficient inhibitory activity against K65R RTSHIV, and this virus had good replicative capacity and virulence. This suggests that, at least when accompanied by other RT mutations, a potential attenuating effect of the K65R mutation on viral replicative capacity is by itself insufficient to explain the reduced viremia during tenofovir therapy. The demonstration of the direct causality between CD8+ cell-mediated immune responses and suppressed K65R viremia in tenofovir-treated animal 30577 is important, as it helps to explain observations in humans, where strong cell-mediated immune responses were associated with the maintenance of low-level viremia in HAART-treated individuals with drug-resistant HIV-1 [75-78].

Because the $\mathrm{cM}-\mathrm{T} 807$ antibody depletes both the CD3+CD8+ T lymphocytes and CD3-CD8+ NK cells, the relative contribution of these 2 cell populations to the immune-mediated suppression of viremia in animal 30577 could not be determined in the current experiment. NK cells are also effector cells of antibody-dependent cellular cytotoxicity (ADCC). In an in vitro assay that measures antibody-dependent cell-mediated virus inhibition, plasma samples of animal 30577 and of tenofovir-treated SIVmac251-infected animals that similarly suppressed K65R viremia to undetectable levels were found to have high antiviral activity in the presence of PBMC effector cells [79]. In these long-term tenofovir-treated SIV or RT- 
SHIV infected animals with undetectable viremia, the antiviral immune responses must be unusually strong and broad, as immune-escape mutants have not emerged even after 6 to 11 years of tenofovir treatment $([20,43]$; unpublished data). Further elucidation of these strong antiviral immune responses (including effector frequency, epitope recognition, etc.) may aid the development of novel immunotherapeutic strategies that combine the strengths of antiviral drugs and the immune system to indefinitely delay disease progression in HIV-infected persons.

Despite this important role of CD8+ cells, continued administration of tenofovir was still required to maintain maximal suppression of K65R viremia in animal 30577; in other words, both antiviral immune responses and tenofovir were needed. This is similar to previous observations in tenofovir-treated animals that were infected with K65R SIV mutants [20]. A recent report also demonstrated that both antiviral immune responses (induced by prior immunization) and short-term tenofovir administration were required to protect macaques against infection after intravenous inoculation with a high dose of a virulent K65R SIV isolate [80]. For RT-SHIV infected animal 30577 , the viral rebound following withdrawal of tenofovir therapy was relatively slow (in comparison to the more rapid and dramatic rebound during CD8+ cell depletion), and consisted of K65R in PBMC-associated infectious virus, but K70E in plasma viral RNA. The reason for this discrepancy in mutations is unclear, but it is plausible that both sources of virus reflect distinct compartments, where differences in the relative role and strength of immunologic and pharmacologic factors may affect virus replication differently upon tenofovir withdrawal. As discussed previously, it is unclear whether the need of continued tenofovir treatment to achieve optimal inhibition of K65R virus replication is due to residual direct antiviral activity of the tenofovir regimen against these mutants (e.g., in antigen-presenting cells), and/or to potential immunomodulatory effects of tenofovir (such as priming of IL12 secretion) that promote the generation and maintenance of strong antiviral immune responses [20,81]. It is important to remember that the effects of antiviral immune responses during drug therapy are not mutually exclusive of the effects of residual drug activity and/or reduced replicative capacity of mutant virus. In particular, even a partial inhibition of virus replication by the drug regimen, or a minor decrease in replicative capacity, can have a major impact on viremia if it provides more opportunity for effective antiviral immune responses to kill productively infected cells prior to the major viral burst. While our macaque studies modeled only the responses to tenofovir monotherapy, such considerations may be even more relevant for HAART-treated humans, as the combination of the K65R mutation with some other drugselected mutations can further decrease viral replication fitness and affect drug susceptibility (including restored susceptibility) to tenofovir or other drugs of the HAART regimen, which may offer additional opportunities for antiviral activity.

\section{Conclusion}

The current findings with RT-SHIV are consistent with but also extend previous observations on the K65R mutation in the SIV model $[20,22,80]$, with the novel observation of the tenofovir-selected K70E mutation (which was not detected by population sequencing in tenofovir-treated SIVmac251-infected macaques). The observations in macaques suggest that for persons infected with K65R HIV-1, both immune-mediated and drug-dependent antiviral activities may play a role in controlling viremia, and that even in the presence of K65R virus, continuation of tenofovir treatment as part of HAART may be beneficial, particularly when assisted by antiviral immune responses. In other words, the detection of K65R may by itself not be a valid reason to withdraw tenofovir from the patient's regimen, unless more effective salvage regimens, which are also feasible in terms of cost, toxicity and compliance are available. While preliminary data already suggest the virologic benefits of including tenofovir in drug regimens for HIV-1 infected patients with K65R mutants [82,83], additional long-term studies are warranted to determine also the potential clinical benefits of continuing tenofovir therapy in the presence of K65R mutants. Such information is also relevant to develop treatment guidelines for resource-poor areas, where access to $2^{\text {nd }}$ or $3^{\text {rd }}$ line antiHIV drugs may be limited, and regular monitoring of virus levels and drug resistance (such as K65R) is not always feasible. Simple treatment strategies for which decisions to alter the regimen would be less dependent on frequent monitoring of such laboratory parameters will be more practical and affordable, and can thus benefit the largest number of people.

\section{Methods \\ Animals}

All rhesus macaques (Macaca mulatta) were juvenile animals from the type D-retrovirus-free and SIV-free colony at the California National Primate Research Center (CNPRC), and were housed in accordance with American Association for Accreditation of Laboratory Animal Care standards, with strict adherence to the "Guide for the Care and Use of Laboratory Animals" [84]. For blood collections, animals were immobilized with $10 \mathrm{mg} / \mathrm{kg}$ intramuscular ketamine-HCL (Parke-Davis, Morris Plains, NJ, USA). Complete blood cell counts were measured by using an automated electronic cell counter (Baker 9000; Serono Baker Diagnostics); differential counts were determined manually. 


\section{In vitro propagation of RT-SHIV}

An infectious cell-free stock of RT-SHIV (which contains the RT of HIV-1 IIIB clone HXBc2; [24]) was prepared following transfection of CEMx174 cells by electroporation, as described previously [31]. Aliquots of cell-free supernatants were stored frozen at $-130^{\circ} \mathrm{C}$. This RT-SHIV stock had a titer of $10^{5} 50 \%$ tissue culture infectious doses $\left(\mathrm{TCID}_{50}\right)$ per ml. This RT-SHIV stock had the T to C substitution at position 8 of the SIV tRNA primer binding site, which is necessary for rapid replication of RT-SHIV in vivo [85].

\section{Animal inoculation and in vivo passage of RT-SHIV}

A first group of 3 animals (group A; Fig. 1) was inoculated intravenously with $1.0 \mathrm{ml}$ of undiluted virus (i.e., $10^{5}$ $\mathrm{TCID}_{50}$ ). Equal volumes of cryopreserved EDTA-anticoagulated plasma collected from the 3 animals at 2 weeks of infection were thawed, pooled and $0.6 \mathrm{ml}$ was administered intravenously to 4 new animals (group B; Fig. 1). Similarly, EDTA-anticoagulated plasma collected from these 4 animals 2 weeks after virus inoculation was pooled and $0.6 \mathrm{ml}$ was administered intravenously to another 5 animals (group C).

\section{Preparation and administration of tenofovir}

Tenofovir (Gilead Sciences) was suspended in distilled water, dissolved by the addition of $\mathrm{NaOH}$ to a final $\mathrm{pH}$ of 7.0 and concentration of $60 \mathrm{mg} / \mathrm{ml}$, filter sterilized $(0.2$ $\mu \mathrm{m}$; Nalgene), and stored at $4^{\circ} \mathrm{C}$. Starting at 20 or 21 weeks after RT-SHIV inoculation, tenofovir was administered subcutaneously into the back of the animal at a once daily dosage regimen of $10 \mathrm{mg} / \mathrm{kg}$ body weight, with dosage changes described in the results section. Animals were monitored regularly by chemistry panels and urinalysis to monitor for renal toxicity that occurs with prolonged high-dose tenofovir regimens, and make the necessary dosage adjustments [36].

\section{Administration of cM-T807}

CD8+ cells were depleted using the previously described cM-T807 antibody [86,87]; a total of $20 \mathrm{mg} / \mathrm{kg}$ body weight was administered in 3 doses: $10 \mathrm{mg} / \mathrm{kg}$ subcutaneously on day 0 , and $5 \mathrm{mg} / \mathrm{kg}$ intravenously 3 and 7 days later. No adverse effects were observed following cM-T807 administration.

\section{Quantitation of plasma viral RNA}

Viral RNA levels in plasma were quantified using a realtime reverse transcription-polymerase chain reaction (RTPCR) assay for SIV gag, described previously [88,89]. With the available plasma volumes, the sensitivity was 30 RNA copies/ml.

\section{Virus isolation}

Infectious virus was isolated in cultures of peripheral blood mononuclear cells (PBMC) with CEMx174 cells and subsequent p27 core antigen measurement, according to methods previously described [90]. Levels of infectious virus in PBMC and plasma were determined by a limiting dilution assay [90].

\section{Drug susceptibility assays}

Phenotypic drug susceptibilities of RT-SHIV isolates were characterized by a previously described assay based on a dose-dependent reduction of viral infectivity [19,91].

\section{Sequence analysis of $R T$-encoding region}

Infected CEMx174 and PBMC co-cultures were harvested as soon as culture supernatants were positive by antigen capture ELISA. Genomic DNA was extracted and used for nested PCR; amplicons were purified with a PCR purification kit (QIAGEN) and used for DNA sequencing according to methods and with primers described previously $[25,31]$. This method can detect the presence of a $20 \%$ subpopulation.

\section{Real-time polymerase chain reaction (PCR) for sensitive detection of K65R and K70E in plasma RT-SHIV RNA}

Sensitive testing for the K65R and K70E mutations was performed using real-time PCR-based methodologies as described previously [92]. Briefly, a 763 nucleotide template of RT-SHIV (n.t. 58 to 821 in RT) was first amplified by RT-PCR using the HIV-1 RT primer RTP-REV (5'-ATC CCT GCA TAA ATC TGA CTT GC) for the reverse transcriptase step followed by addition of forward primer RTP-F2 (5'-AAA GTT AAA CAA TGG CCA TTG ACA G) for PCR amplification.

The real-time PCR reactions were performed in duplicate using $2 \mu$ l of the RT-PCR products for both the total virus copy and mutation-specific tests. Total SHIV RT templates were detected with the primers ComFWD and ComREV, which span n.t. 258-420 in RT, along with the common probe 1 . The reactions for detecting the K65R mutation involved the mutation-specific primer HIV-RT 65R.FWD with the primer 65R.REV and FAM-labeled probes mixture, $1 \mathrm{P}(80 \%)$ and $2 \mathrm{P}(20 \%)$. The K70E test used the mutation-specific primer 70E.REV with the primer 70.FWD and probe 70.2P. Differences in total copy and mutation-specific amplification curves $(\Delta \mathrm{CT})$ of $\leq 9$ or $\leq$ 10 cycles indicated the presence of $65 \mathrm{R}$ and $70 \mathrm{E}$, respectively. These assay cutoffs allowed mutant viruses to be detected at frequencies $\geq 0.4 \%$.

\section{Mutation linkage analysis}

To evaluate the interplay of the mutations during emergence, the positive mutation-specific amplicons were directly sequenced using the primers 65-118SEQ.1R (5'- 
CTA GGT ATG GTA AAT GCA GTA TAC TTC CT) and RTSEQ.2F (5'-AAG GAA GGG AAA ATT TCA AAA ATT GGG $\mathrm{CC)}$ for the K65R amplicon and K70E amplicon, respectively. The overlapping amplicon sequences allowed for visualization of the adjacent codons.

\section{Detection of SIV-specific immune responses}

The ELISA to detect SIV-specific immunoglobulin G (IgG) in plasma samples was performed as described previously [22].

\section{Lymphocyte phenotyping}

Initially, 3-color flow cytometry techniques were used to detect CD3, CD4, CD8 and CD20 with fluorochromeconjugated antibodies described previously [93,94]. Starting at approximately 145 weeks of infection, 4-color flow cytometry techniques were used, consisting of a single tube containing antibodies to CD3, CD4, CD8 and CD20, as described previously [20]. CD4+ T lymphocytes and CD8+ T lymphocytes were defined as CD3+CD4+ and CD3+CD8+ lymphocyte populations, respectively. B lymphocytes were defined as CD3-CD20+ lymphocytes. NK cells were defined as CD3-CD8+ lymphocytes. During the CD8+ cell depletion experiment, the anti-CD8 antibody was replaced by the DK25 clone (DAKO, Carpinteria, California) conjugated to FITC (and combined with antiCD3-PerCP, anti-CD4-PE and anti-CD20-APC as decribed previously [20]).

\section{Genetic assessment of MHC class I alleles}

DNA extracted from lymphoid cells (with QIAamp ${ }^{\circledast}$ DNA mini kit, QIAgen, Valencia, CA) was used to screen for the presence of the major histocompatibility complex (MHC) class I alleles Mamu-A*01 and Mamu-B*01, using a PCRbased technique $[95,96]$. The frequency of Mamu-A*01 and Mamu-B*01 alleles in the CNPRC rhesus macaque colony is approximately $25 \%$.

\section{Criteria for euthanasia and animal necropsies}

Euthanasia of animals with simian AIDS was performed when clinical observations indicated a severe life-threatening situation for the animal, as described previously [22]. A complete necropsy with a routine histopathologic examination of tissues was performed. Tissues were fixed in $10 \%$ buffered formalin, embedded in paraffin, sectioned at $6 \mu \mathrm{m}$, stained with hematoxylin and eosin, and examined by light microscopy.

\section{Statistical analysis}

Statistical analyses were performed with Prism Version 4.0 and Instat Version 3.0a (GraphPad Software Inc. San Diego, CA). All statistical analyses of viral RNA levels in plasma were performed after log-transformation of the values.

\section{Competing interests}

This study was partially supported by Gilead Sciences.

\section{Authors' contributions}

KKAVR was responsible for the overall design of the study, sample processing, data analysis and preparation of the first draft of the manuscript. JAJ, JL and WH contributed all real-time PCR data including data analysis and interpretation. EJB, RPS and TBM performed DNA sequence analysis, virus isolations and data entry. NB assisted with pharmacokinetic analyses and data interpretation. MLM, NCP, and TWN assisted with the study design and data interpretation. All authors were involved in revising the manuscript draft and approved the final manuscript.

\section{Acknowledgements}

For their technical assistance, we thank R. Askea, D. Bennett, I. Cazares, T. Dearman, N. Dowell, J. Higgins, L. Hirst, L. Lawson, J. Murry, W. von Morgenland, the Veterinary Staff, Colony Services and Clinical Laboratory of the California National Primate Research Center and Center for Comparative Medicine (UC Davis); M. Miller (Gilead Sciences) for useful discussions and review of the manuscript; the Quantitative Molecular Diagnostics Core of the AIDS Vaccine Program, SAIC Frederick, Inc, National Cancer Institute, Frederick, Frederick, MD 2I70I for assistance with plasma viral RNA load determinations; Keith Reimann (Harvard Medical School) for provision of CM-T807; the CM-T807 antibody used in this study was produced by the National Cell Culture Center and with funds provided by NIH grant RRI600I.

This work was supported by Gilead Sciences, NIH/NIAID grants ROI RRI3967 and ROI Al47070 (T.W.N), and Grant RR00I69 from the National Center for Research Resources (NCRR), a component of the National Institutes of Health (NIH). The findings and conclusions in this paper are those of the authors and do not necessarily reflect the views of the Centers for Disease Control and Prevention.

\section{References}

I. Margot NA, Isaacson E, McGowan I, Cheng A, Miller MD: Extended treatment with tenofovir disoproxil fumarate in treatmentexperienced HIV-I-infected patients: genotypic, phenotypic, and rebound analyses. J Acquir Immune Defic Syndr 2003, 33: I 5-2I.

2. Wainberg MA, Miller MD, Quan Y, Salomon H, Mulato AS, Lamy PD, Margot NA, Anton KE, Cherrington JM: In vitro selection and characterization of HIV-I with reduced susceptibility to PMPA. Antivir Ther 1999, 4:87-94.

3. Gallant JE, Staszewski S, Pozniak AL, Dejesus E, Suleiman JM, Miller MD, Coakley DF, Lu B, Toole J], Cheng AK: Efficacy and safety of tenofovir DF vs stavudine in combination therapy in antiretroviral-naive patients: a 3-year randomized trial. JAMA 2004, 292: $19 \mid-201$.

4. Mauss S, Milinkovic A, Hoffman C, Holm S, Berger F, Martínez E: Low rate of treatment failure on antiretroviral therapy with tenofovir, lamivudine and zidovudine. AIDS 2005, I9:10I-I03.

5. McColl DJ, Margot NA, Wulfsohn M, Coakley DF, Cheng AK, Miller MD: Patterns of resistance emerging in HIV-I from antiretroviral-experienced patients undergoing intensification therapy with tenofovir disoproxil fumarate. J Acquir Immune Defic Syndr 2004, 37: 1340-1350.

6. Maitland D, Moyle G, Hand J, Mandalia S, Boffito M, Nelson M, Gazzard $B$ : Early virologic failure in HIV-I infected subjects on didanosine/tenofovir/efavirenz: | 2-week results from a randomized trial. AIDS 2005, 19: II83-II88.

7. Delaunay C, Brun-Vezinet F, Landman R, Collin G, Peytavin G, Trylesinski A, Flandre P, Miller M, Descamps D: Comparative selection of the K65R and MI84V/I mutations in human immunodefi- 
ciency virus type $\mathrm{I}$-infected patients enrolled in a trial of first-line triple-nucleoside analog therapy (Tonus IMEA $02 \mathrm{I}$ ). J Virol 2005, 79:9572-9578.

8. Wirden M, Marcelin AG, Tubiana R, Valantin MA, Ghosn J, Duvivier C, Dominguez S, Paris L, Agher R, Peytavin G, et al:: Virologic outcome after switching from a nucleoside reverse transcriptase inhibitor to tenofovir in patients with undetectable HIV-I RNA plasma level. J Acquir Immune Defic Syndr 2004, 36:876-878.

9. Ruane PJ, Luber AD: K65R-Associated virologic failure in HIVinfected patients receiving tenofovir-containing triple nucleoside/nucleotide reverse transcriptase inhibitor regimens. MedGenMed 2004, 6:3I.

10. Kuritzkes DR: Less than the sum of its parts: failure of a tenofovir-abacavir-Lamivudine triple-nucleoside regimen. J Infect Dis 2005, 192:1867-1868.

II. Gallant JE, Rodriguez AE, Weinberg WG, Young B, Berger DS, Lim ML, Liao Q, Ross L, Johnson J, Shaefer MS: Early virologic nonresponse to tenofovir, abacavir, and lamivudine in HIVinfected antiretroviral-naive subjects. J Infect Dis 2005, 192:1921-1930.

12. Hirsch MS, Brun-Vezinet F, Clotet B, Conway B, Kuritzkes DR, D'Aquila RT, Demeter LM, Hammer SM, Johnson VA, Loveday C, et al.: Antiretroviral drug resistance testing in adults infected with human immunodeficiency virus type I: 2003 recommendations of an International AIDS Society-USA Panel. Clin Infect Dis 2003, 37: I I3-128.

13. White KL, Margot NA, Wrin T, Petropoulos CJ, Miller MD, Naeger LK: Molecular mechanisms of resistance to human immunodeficiency virus type I with reverse transcriptase mutations $K 65 R$ and $K 65 R+M I 84 V$ and their effects on enzyme function and viral replication capacity. Antimicrob Agents Chemother 2002, 46:3437-3446

14. Wirden M, Malet I, Derache A, Marcelin AG, Roquebert B, Simon A, Kirstetter M, Joubert LM, Katlama C, Calvez V: Clonal analyses of HIV quasispecies in patients harbouring plasma genotype with K65R mutation associated with thymidine analogue mutations or L74V substitution. AIDS 2005, 19:630-632.

15. Deval J, Navarro JM, Selmi B, Courcambeck J, Boretto J, Halfon P, Garrido-Urbani S, Sire J, Canard B: A loss of viral replicative capacity correlates with altered DNA polymerization kinetics by the human immunodeficiency virus reverse transcriptase bearing the K65R and L74V dideoxynucleoside resistance substitutions. J Biol Chem 2004, 279:25489-25496.

16. Moyle G]: The K65R mutation: selection, frequency, and possible consequences. AIDS Read 2004, 14:595-597. 60I-593.

17. Parikh UM, Barnas DC, Faruki H, Mellors JW: Antagonism between the HIV-I reverse-transciptase mutation K65R and thymidine-analogue mutations at the genomic level. J Infect Dis 2006, 194:65।-660.

18. Van Rompay KKA, Greenier JL, Marthas ML, Otsyula MG, Tarara RP, Miller CJ, Pedersen NC: A zidovudine-resistant simian immunodeficiency virus mutant with a QI5 IM mutation in reverse transcriptase causes AIDS in newborn macaques. Antimicrob Agents Chemother 1997, 41:278-283.

19. Van Rompay KKA, Cherrington JM, Marthas ML, Berardi C], Mulato AS, Spinner A, Tarara RP, Canfield DR, Telm S, Bischofberger N, Pedersen NC: 9-[2-(Phosphonomethoxy)propyl] adenine therapy of established simian immunodeficiency virus infection in infant rhesus macaques. Antimicrob Agents Chemother 1996, 40:2586-2591.

20. Van Rompay KKA, Singh RP, Pahar B, Sodora DL, Wingfield C, Lawson JR, Marthas ML, Bischofberger N: CD8+ cell-mediated suppression of virulent simian immunodeficiency virus during tenofovir treatment. J Virol 2004, 78:5324-5337.

21. Van Rompay KKA, Cherrington JM, Marthas ML, Lamy PD, Dailey PJ, Canfield DR, Tarara RP, Bischofberger N, Pedersen NC: 9-[2(Phosphonomethoxy)propyl]adenine (PMPA) therapy prolongs survival of infant macaques inoculated with simian immunodeficiency virus with reduced susceptibility to PMPA. Antimicrob Agents Chemother 1999, 43:802-8I2.

22. Van Rompay KK, Singh RP, Brignolo LL, Lawson JR, Schmidt KA Pahar B, Canfield DR, Tarara RP, Bischofberger N, Marthas ML: The clinical benefits of tenofovir for simian immunodeficiency virus-infected macaques are larger than predicted by its effects on standard viral and immunologic parameters. Acquir Immune Defic Syndr 2004, 36:900-9I4.

23. Witvrouw M, Pannecouque C, Switzer WM, Folks TM, De Clercq E, Heneine W: Susceptibility of HIV-2, SIV and SHIV to various anti-HIV-I compounds: implications for treatment and postexposure prophylaxis. Antivir Ther 2004, 9:57-65.

24. Uberla K, Stahl-Hennig C, Böttiger D, Mätz-Rensing K, Kaup FJ, Li J, Haseltine WA, Fleckenstein B, Hunsmann G, Öberg B, Sodroski J: Animal model for the therapy of acquired immunodefiency syndrome with reverse transcriptase inhibitors. Proc Natl Acad Sci USA 1995, 92:8210-8214.

25. North TW, Van Rompay KKA, Higgins J, Matthews TB, Wadford DA, Pedersen NC, Schinazi RF: Suppression of virus load by highly active antiretroviral therapy in rhesus macaques infected with a recombinant simian immunodeficiency virus containing reverse transcriptase from human immunodeficiency virus type I. J Virol 2005, 79:7349-7354.

26. Rosenwirth B, ten Haaft P, Bogers WMJM, Nieuwenhuis IG, Niphuis H, Kuhn E-M, Bischofberger N, Heeney JL, Überla K: Antiretroviral therapy during primary immunodeficiency virus infection can induce persistent suppression of virus load and protection from heterologous challenge in rhesus macaques. J Virol 2000, 74: I704-I7II.

27. Ten Haaft P, Verstrepen B, Überla K, Rosenwirth B, Heeney J: A pathogenic threshold of virus load defined in simian immunodeficiency virus- or simian-human immunodeficiency virusinfected macaques. J Virol 1998, 72: 1028I-10285

28. Mori K, Yasumoti Y, Sawada S, Villinger F, Sugama K, Rosenwirth B, Heeney JL, Überla K, Yamazaki S, Ansari AA, Rübsammen-Waigmann $\mathrm{H}$ : Suppression of acute viremia by short-term postexposure prophylaxis of simian/human immunodeficiency virus SHIV$\mathrm{RT}$-infected monkeys with a novel reverse transcriptase inhibitor (GW420867) allows for development of potent antiviral immune responses resulting in efficient containment of infection. J Virol 2000, 74:5747-5753

29. Rosenwirth B, Bogers WM, Nieuwenhuis IG, Haaft PT, Niphuis $H$, Kuhn EM, Bischofberger N, Erfle V, Sutter G, Berglund P, et al.: An anti-HIV strategy combining chemotherapy and therapeutic vaccination. J Med Primatol 1999, 28:195-205.

30. Deeks SG, Barditch-Crovo P, Lietman PS, Hwang F, Cundy KC Rooney JF, Hellmann NS, Safrin S, Kahn J: Safety, pharmacokinetics and antiretroviral activity of intravenous 9-[2-(R)(Phosphonomethoxy)propyl]adenine, a novel anti-human immunodeficiency virus (HIV) therapy, in HIV-infected adults. Antimicrob Agents Chemother 1998, 42:2380-2384.

31. Hofman MJ, Higgins J, Matthews TB, Pedersen NC, Tan C, Schinazi RF, North TW: Efavirenz therapy in rhesus macaques infected with a chimera of simian immunodeficiency virus containing reverse transcriptase from human immunodeficiency virus type I. Antimicrob Agents Chemother 2004, 48:3483-3490.

32. Balzarini J, De Clercq E, Überla K: SIV/HIV-I hybrid virus expressing the reverse transcriptase gene of HIV-I remains sensitive to HIV-I-specific reverse transcriptase inhibitors after passage in rhesus macaques. J Acquir Immune Defic Syndr Hum Retrovirol 1997, 1 5: I-4.

33. Wadford DA, Higgins I, Van Rompay KKA, Pedersen NC, North TW Variation of human immunodeficiency virus type-I reverse transcriptase within the simian immunodeficiency virus genome of RT-SHIV. 2007 in press.

34. Margot NA, Waters JM, Miller MD: In vitro human immunodeficiency virus type $I$ resistance selections with combinations of tenofovir and emtricitabine or abacavir and Lamivudine. Antimicrob Agents Chemother 2006, 50:4087-4095.

35. White KL, Chen JM, Margot NA, Wrin T, Petropoulos CJ, Naeger LK, Swaminathan S, Miller MD: Molecular mechanisms of tenofovir resistance conferred by human immunodeficiency virus type I reverse transcriptase containing a diserine insertion after residue 69 and multiple thymidine analog-associated mutations. Antimicrob Agents Chemother 2004, 48:992-1003.

36. Van Rompay KKA, Brignolo LL, Meyer DJ, Jerome C, Tarara R, Spinner A, Hamilton M, Hirst LL, Bennett DR, Canfield DR, et al.: Biological effects of short-term and prolonged administration of 9 . [2-(phosphonomethoxy)propyl]adenine (PMPA; tenofovir) to newborn and infant rhesus macaques. Antimicrob Agents Chemother 2004, 48:1469-1487. 
37. Will a pill a day prevent HIV? Anticipating the results of the tenofovir "PREP" trials [http://avac.org/pdf/tenofovir.pdf]

38. Horton H, Vogel TU, Carter DK, Vielhuber K, Fuller DH, Shipley T, Fuller JT, Kunstman KJ, Sutter G, Montefiori DC, et al.: Immunization of rhesus macaques with a DNA prime/modified vaccinia virus Ankara boost regimen induces broad simian immunodeficiency virus (SIV)-specific T-cell responses and reduces initial viral replication but does not prevent disease progression following challenge with pathogenic SIVmac239. Jirol 2002, 76:7187-7202.

39. Lifson JD, Piatak M Jr, Cline AN, Rossio JL, Purcell J, Pandrea I, Bischofberger N, Blanchard J, Veazey RS: Transient early postinoculation anti-retroviral treatment facilitates controlled infection with sparing of CD4+ T cells in gut-associated lymphoid tissues in SIVmac239-infected rhesus macaques, but not resistance to rechallenge. J Med Primatol 2003, 32:20I-2I0.

40. Mothé BR, Weinfurter J, Wang C, Rehrauer W, Wilson N, Allen TM, Allison DB, Watkins DI: Expression of the major histocompatibility complex class I molecule Mamu-A*0I is associated with control of simian immunodeficiency virus SIVmac239 replication. J Virol 2003, 77:2736-2740.

4I. Mothe BR, Horton H, Carter DK, Allen TM, Liebl ME, Skinner P, Vogel TU, Fuenger S, Vielhuber K, Rehrauer W, et al: Dominance of CD8 responses specific for epitopes bound by a single major histocompatibility complex class I molecule during the acute phase of viral infection. J Virol 2002, 76:875-884

42. Hazuda DJ, Young SD, Guare JP, Anthony NJ, Gomez RP, Wai JS, Vacca JP, Handt L, Motzel SL, Klein HJ, et al.: Integrase inhibitors and cellular immunity suppress retroviral replication in rhesus macaques. Science 2004, 305:528-532.

43. Van Rompay KKA: Antiretroviral drug studies in non-human primates: a valid animal model for innovative drug efficacy and pathogenesis studies. AIDS Reviews 2005, 7:67-83.

44. Resino S, Bellón JM, Sánchez-Ramón S, Gurbindo D, León JA, MunozFernández $A: C D 8+T$-cell numbers predict the response to antiviral therapy in HIV-I infected children. Pediatr Res 2003, 53:309-312.

45. Wood E, Hogg RS, Yip B, Harrigan PR, Montaner JS: Why are baseline HIV RNA levels I 00,000 copies/mL or greater associated with mortality after the initiation of antiretroviral therapy? J Acquir Immune Defic Syndr 2005, 38:289-295.

46. Buseyne F, Scott-Algara D, Bellal N, Burgard M, Rouzioux C, Blanche $S$, Riviere $Y$ : The frequency of HIV-specific interferon-gammaproducing CD8 $\mathrm{T}$ cells Is associated with both age and level of antigenic stimulation in HIV-I-infected children. J Infect Dis 2005, 192: 178I-1786.

47. Phillips AN, Staszewski S, Weber R, Kirk O, Francioli P, Miller V, Vernazza $P$, Lundgren JD, Ledergerber B: HIV viral load response to antiretroviral therapy according to the baseline CD4 cell count and viral load. JAMA 200I, 286:2560-2567.

48. Malhotra U, Holte S, Dutta S, Berrey MM, Delpit E, Koelle DM, Sette A, Corey L, McElrath MJ: Role for HLA class II molecules in HIVI suppression and cellular immunity following antiretrovira treatment. J Clin Invest 200I, 107:505-5I7.

49. Blankson JN, Siliciano RF: MHC class II genotype and the control of viremia in HIV-I-infected individuals on highly active antiretroviral therapy. J Clin Invest 200I, 107:549-55I.

50. Schooley RT, Ruane P, Myers RA, Beall G, Lampiris H, Berger D, Chen S-S, Miller MD, Isaacson E, Cheng AK, for the Study 902 Team: Tenofovir DF in antiretroviral-experienced patients: results from a 48-week, randomized, double-blind study. AIDS 2002 16:1257-1263

5I. Barditch-Crovo P, Deeks SG, Collier A, Safrin S, Coakley DF, Miller M, Kearney BP, Coleman RL, Lamy PD, Kahn JO, et al: Phase I/II trial of the pharmacokinetics, safety, and antiretroviral activity of tenofovir disoproxil fumarate in HIV-I infected adults. Antimicrob Agents Chemother 200I, 45:2733-2739.

52. Louie M, Hogan C, Hurley A, Simon V, Chung C, Padte N, Lamy P, Flaherty J, Coakley D, Di Mascio M, et al.: Determining the antiviral activity of tenofovir disoproxil fumarate in treatmentnaive chronically HIV-I-infected individuals. AIDS 2003, I7:| I5I-II56.

53. Lloyd RMJ, Huong J, Rouse E, Gerondelis P, Lim M, Shaefer M, Rodriguez A, Gallant J, Lanier R, Ross LL: HIV-I RT mutations K70E and $K 65 R$ are not present on the same viral genome when both mutations are detected in plasma. 45th Annual ICAAC-
Interscience Conference on Antimicrobial Agents and Chemotherapy; Washington, D.C 2005

54. Ross L, Gerondelis P, Liao Q, Wine B, Lim M, Shaefer M, Rodriguez A, Gallant J, Limoli K, Huang W, et al.: Selection of the HIV-I reverse transcriptase mutation K70E in antiretroviral-naïve subjects treated with tenofovir/abacavir/lamivudine therapy. Antiviral Therapy 2005, 10:S102.

55. Mulato AS, Lamy PD, Miller MD, Li W-X, Anton KE, Hellmann NS, Cherrington JM: Genotypic and phenotypic characterization of human immunodeficiency virus type I variants isolated from AIDS patients after prolonged adefovir dipivoxil therapy. Antimicrob Agents Chemother 1998, 42:1620-1628.

56. Cherrington JM, Mulato AS, Fuller MD, Chen MS: Novel mutation (K70E) in human immunodeficiency virus type I reverse transcriptase confers decreased susceptibility to 9-[2(phosphonomethoxy)ethyl]adenine in vitro. Antimicrob Agents Chemother 1996, 40:2212-2216.

57. Delaugerre C, Roudiere L, Peytavin G, Rouzioux C, Viard JP, Chaix ML: Selection of a rare resistance profile in an HIV-I-infected patient exhibiting a failure to an antiretroviral regimen including tenofovir DF. J Clin Virol 2005, 32:24I-244.

58. Kagan R, Ross L, Winters M, Merigan T, Heseltine P, Lewinski M: Adefovir-associated HIV-I RT mutation K70E in the age of tenofovir. Antiviral Therapy 2005, 10:SI03.

59. HIV Drug Resistance Database [http://hivdb.stanford.edu/]

60. Miller MD, Lamy PD, Fuller MD, Mulato AS, Margot NA, Cihlar T, Cherrington JM: Human immunodeficiency virus type I reverse transcriptase expressing the K70E mutation exhibits a decrease in specific activity and processivity. Mol Pharmacol 1998, 54:29|-297.

6I. Frost SDW, Nijhuis M, Schuurman R, Boucher CAB, Leigh Brown AJ Evolution of lamivudine resistance in human immunodeficiency virus type I-infected individuals: the relative roles of drift and selection. I Virol 2000, 74:6262-6268.

62. Tsai C-C, Follis KE, Beck TW, Sabo A, Grant RF, Bischofberger N, Benveniste RE: Prevention of simian immunodeficiency virus infection in macaques by 9-(2-phosphonylmethoxypropyl)adenine (PMPA). Science 1995, 270: I I97- I 199.

63. Lifson JD, Rossio JL, Arnaout R, Li L, Parks TL, Schneider DK, Kiser RF, Coalter VJ, Walsh G, Imming RJ, et al.: Containment of simian immunodeficiency virus infection: cellular immune responses and protection from rechallenge following transient postinoculation antiretroviral treatment. J Virol 2000 74:2584-2593.

64. Silvera P, Racz P, Racz K, Bischofberger N, Crabbs C, Yalley-Ogunro J, Greenhouse J, Bo Jiang J, Lewis MG: Effect of PMPA and PMEA on the kinetics of viral load in simian immunodeficiency virus-infected macaques. AIDS Res Hum Retroviruses 2000, 16:79I-800

65. Miller MD, Margot N, Lu B, Zhong L, Chen SS, Cheng A, Wulfsohn M: Genotypic and phenotypic predictors of the magnitude of response to tenofovir disoproxil fumarate treatment in antiretroviral-experienced patients. I Infect Dis 2004, 189:837-846.

66. Rhee SY, Fessel WJ, Zolopa AR, Hurley L, Liu T, Taylor J, Nguyen DP, Slome S, Klein D, Horberg M, et al: HIV-I Protease and reversetranscriptase mutations: correlations with antiretroviral therapy in subtype $B$ isolates and implications for drugresistance surveillance. J Infect Dis 2005, 192:456-465.

67. Khanlou H, Yeh V, Guyer B, Farthing C: Early virologic failure in a pilot study evaluating the efficacy of therapy containing once-daily abacavir, lamivudine, and tenofovir DF in treatment-naive HIV-infected patients. AIDS Patient Care STDS 2005 , 19:135-140

68. Castagna A, Danise A, Menzo S, Galli L, Gianotti N, Carini E, Boeri E, Galli A, Cernuschi M, Hasson $H$, et al.: Lamivudine monotherapy in HIV-I-infected patients harbouring a lamivudine-resistant virus: a randomized pilot study (E-I84V study). AIDS 2006, 20:795-803

69. Danise A, Tiberi S, Galli L, et al.: Lamivudine monotherapy in failing HIV-I infected subjects, harbouring the MI84V mutation: 72-week follow-up. Programs and abstracts of the 10th European AIDS Conference, November 17-20; Dublin, Ireland 2005.

70. Deeks SG, Hoh R, Neilands TB, Liegler T, Aweeka F, Petropoulos CJ, Grant RM, Martin JN: Interruption of treatment with individual 
therapeutic drug classes in adults with multidrug-resistant HIV-I infection. J Infect Dis 2005, I 92: I537-I544.

7I. Kuritzkes DR, Quinn JB, Benoit SL, Shugarts DL, Griffin A, Bakhtiari $M$, Poticha D, Eron J], Fallon MA, Rubin M: Drug resistance and virologic response in NUCA $300 \mathrm{I}$, a randomized trial of lamivudine (3TC) versus zidovudine (ZDV) versus ZDV plus 3TC in previously untreated patients. AIDS 1996, 10:975-98I.

72. Eron JJ, Benoit SL, Jemsek J, MacArthur RD, Santana J, Quinn JB, Kuritzkes DR, Fallon MA, Rubin M, for the North American HIV Working Group: Treatment with lamivudine, zidovudine, or both in HIV-positive patients with 200 to 500 CD4+ cells per cubic millimeter. N Engl J Med 1995, 333: I662-I669.

73. Schuurman R, Nijhuis M, R. VL, Schipper P, De Jong D, Collis P, Danner SA, Mulder J, Loveday C, Christoperson C, et al.: Rapid changes in human immunodeficiency virus type I RNA load and appearance of drug-resistant virus populations in persons treated with lamivudine (3TC). J Infect Dis | 995, | $7 \mid$ : | |4||-| $4 \mid$ | 9 .

74. Richman DD, Havlir D, Corbeil J, Looney D, Ignacio C, Spector SA, Sullivan J, Cheeseman S, Barringer K, Pauletti D, et al.: Nevirapine resistance mutations of human immunodeficiency virus type I selected during therapy. J Virol I994, 68:1660-1666.

75. Emu B, Sinclair E, Favre D, Moretto WJ, Hsue P, Hoh R, Martin JN, Nixon DF, McCune JM, Deeks SG: Phenotypic, functional, and kinetic parameters associated with apparent $\mathrm{T}$-cell control of human immunodeficiency virus replication in individuals with and without antiretroviral treatment. J Virol 2005, 79:14169-14178.

76. Deeks SG, Martin JN, Sinclair E, Harris J, Neilands TB, Maecker HT, Hagos E, Wrin T, Petropoulos CJ, Bredt B, McCune JM: Strong cellmediated immune responses are associated with the maintenance of low-level viremia in antiretroviral-treated individuals with drug-resistant human immunodeficiency virus type I. J Infect Dis 2004, 189:3 12-321.

77. Alatrakchi N, Duvivier C, Costagliola D, Samri A, Marcelin A, Kamkamidze G, Astriti M, Agher R, Calvez V, Autran B, Katlama C: Persistent low viral load on antiretroviral therapy is associated with T cell-mediated control of HIV replication. AIDS 2005, 19:25-33.

78. Price DA, Scullard G, Oxenius A, Braganza R, Beddows SA, Kazmi S, Clarke JR, Johnson GE, Weber JN, Phillips AN: Discordant outcomes following failure of antiretroviral therapy are associated with substantial differences in human immunodeficiency virus-specific cellular immunity. J Virol 2003, 77:604I-6049.

79. Forthal DN, Landucci G, Cole KS, Marthas M, Becerra JC, Van Rompay K: Rhesus macaque polyclonal and monoclonal antibodies inhibit simian immunodeficiency virus in the presence of human or autologous rhesus effector cells. J Virol 2006, 80:9217-9225

80. Metzner KJ, Binley JM, Gettie A, Marx P, Nixon DF, Connor RI: Tenofovir treatment augments anti-viral immunity against drugresistant SIV challenge in chronically infected rhesus macaques. Retrovirology 2006, 3:97.

81. Van Rompay KKA, Marthas ML, Bischofberger N: Tenofovir primes rhesus macaque cells in vitro for enhanced interleukin- 12 secretion. Antiviral Res 2004, 63:133-138.

82. Nevins AB, Wirden M, Rhee SY, Taylor J, Fessel WJ, Horberg M, Scarsella A, Lee SY, Towner W, Calvez V, et al.: Virological response to antiretroviral therapy in the setting of the K65R mutation. Antiviral Therapy 2006, II:S92.

83. Chappell B, Margot NA, Miller MD: Long-term virologic followup of patients taking tenofovir DF with low-level HIV-I viremia and the K65R mutation in HIV-I RT. 45th Interscience Conference on Antimicrobial Agents and Chemotherapy; Washington, DC (Dec. 16-19) 2005.

84. National Research Council: Guide for the care and use of laboratory animals Washington, D. C.: National Academy Press; 1996.

85. Soderberg K, Denekamp L, Nikiforow S, Sautter K, Desrosiers RC, Alexander L: A nucleotide substitution in the tRNA(Lys) primer binding site dramatically increases replication of recombinant simian immunodeficiency virus containing a human immunodeficiency virus type I reverse transcriptase. J Virol 2002, 76:5803-5806.

86. Schmitz JE, Kuroda MJ, Santra S, Sasseville VG, Simon MA, Lifton MA, Racz P, Tenner-Racz K, Dalesandro M, Scallon BJ, et al.: Control of viremia in simian immunodeficiency virus infection by CD8+ T lymphocytes. Science 1999, 283:857-860.

87. Schmitz JE, Simon MA, Kuroda MJ, Lifton MA, Ollert MW, Vogel CW, Racz P, Tenner-Racz K, Scallon BJ, Dalesandro M, et al: A nonhuman primate model for the selective elimination of CD8+ lymphocytes using a mouse-human chimeric monoclonal antibody. Am J Pathol 1999, I 54:1923-1932.

88. Cline AN, Bess JW, Piatak M Jr, Lifson JD: Highly sensitive SIV plasma viral load assay: practical considerations, realistic performance expectations, and application to reverse engineering of vaccines for AIDS. J Med Primatol 2005, 34:303-3I2.

89. Lifson JD, Rossion JL, Piatak MJ, Parks T, Li L, Kiser R, Coalter V, Fisher B, Flynn BM, Czajak S, et al:: Role of CD8+ lymphocytes in control of simian immunodeficiency virus infection and resistance to rechallenge after transient early antiretroviral treatment. J Virol 2001, 75:10187-10199.

90. Van Rompay KKA, Marthas ML, Ramos RA, Mandell CP, McGowan EK, Joye SM, Pedersen NC: Simian immunodeficiency virus (SIV) infection of infant rhesus macaques as a model to test antiretroviral drug prophylaxis and therapy: oral 3'-azido-3'deoxythymidine prevents SIV infection. Antimicrob Agents Chemother 1992, 36:2381-2386.

91. Van Rompay KKA, Otsyula MG, Marthas ML, Miller CJ, McChesney $M B$, Pedersen NC: Immediate zidovudine treatment protects simian immunodeficiency virus-infected newborn macaques against rapid onset of AIDS. Antimicrob Agents Chemother 1995, 39:|25-|3|.

92. Johnson JA, Van Rompay KKA, Delwart E, Heneine W: A sensitive real-time $P C R$ assay for the K65R drug resistance mutation in SIV reverse transcriptase. AIDS Res Hum Retroviruses 2006, 22:912-916.

93. Van Rompay KKA, Dailey PJ, Tarara RP, Canfield DR, Aguirre NL, Cherrington JM, Lamy PD, Bischofberger N, Pedersen NC, Marthas ML: Early short-term 9-[2-(phosphonomethoxy)propyl]adenine (PMPA) treatment favorably alters subsequent disease course in simian immunodeficiency virus-infected newborn rhesus macaques. J Virol 1999, 73:2947-2955.

94. Van Rompay KKA, Matthews TB, Higgins J, Canfield DR, Tarara RP, Wainberg MA, Schinazi RF, Pedersen NC, North TW: Virulence and reduced fitness of simian immunodeficiency virus with the MI84V mutation in reverse transcriptase. J Virol 2002, 76:6083-6092.

95. Knapp LA, Lehmann E, Piekarczyk MS, Urvater JA, Watkins DI: A high frequency of Mamu-A*0I in the rhesus macaque detected by polymerase chain reaction with sequence-specific primers and direct sequencing. Tissue Antigens 1997, 50:657-661.

96. Evans DT, Knapp LA, Jing P, Mitchen JL, Dykhuizen M, Montefiori DC, Pauza CD, Watkins DI: Rapid and slow progressors differ by a single MHC class I haplotype in a family of MHC-defined rhesus macques infected with SIV. Immunol Lett 1999, 66:53-59.

Publish with Bio Med Central and every scientist can read your work free of charge

"BioMed Central will be the most significant development for disseminating the results of biomedical research in our lifetime. "

Sir Paul Nurse, Cancer Research UK

Your research papers will be:

- available free of charge to the entire biomedical community

- peer reviewed and published immediately upon acceptance

- cited in PubMed and archived on PubMed Central

- yours - you keep the copyright 